\title{
Post Drought Population Status and Trend of Specialized Browsers in the Mid Kenya-Tanzania Borderland
}

\author{
Moses Makonjio Okello ${ }^{1,2 *}$, John Warui Kiringe', Philip Muruthi' ${ }^{3}$, Lekishon Kenana4, Hanori Maliti ${ }^{5}$, \\ Noah Wasilwa Sitati ${ }^{3}$, Erastus Kanga ${ }^{4}$, Fiesta Warinwa ${ }^{3}$, Samwel Bakari ${ }^{5}$, Stephen Ndambuki ${ }^{4}$, \\ Nathan Gichohi' ${ }^{3}$ Edeus Massawe5, David Kimutai', Machoke Mwita5, Daniel Muteti4
}

\author{
${ }^{1}$ SFS Center for Wildlife Management, Nairobi, Kenya \\ ${ }^{2}$ Moi University, Department of Tourism, Eldoret, Kenya \\ ${ }^{3}$ African Wildlife Foundation, Nairobi, Kenya \\ ${ }^{4}$ Kenya Wildlife Service, Nairobi, Kenya \\ ${ }^{5}$ Tanzania Wildlife Research Institute, Arusha, Tanzania \\ Email:*mokello33@gmail.com
}

How to cite this paper: Okello, M.M., Kiringe, J.W., Muruthi, P., Kenana, L., Maliti, H., Sitati, N.W., Kanga, E., Warinwa, F., Bakari, S., Ndambuki, S., Gichohi, N., Massawe, E., Kimutai, D., Mwita, M. and Muteti, D. (2016) Post Drought Population Status and Trend of Specialized Browsers in the Mid Kenya-Tanzania Borderland. Natural Resources, 7, 580-610.

http://dx.doi.org/10.4236/nr.2016.710048

Received: March 22, 2016

Accepted: October 28, 2016

Published: October 31, 2016

Copyright $\odot 2016$ by authors and Scientific Research Publishing Inc. This work is licensed under the Creative Commons Attribution International License (CC BY 4.0).

http://creativecommons.org/licenses/by/4.0/ (c) (i) Open Access

\section{Abstract}

We examined the population status, trend and distribution of Gerenuk, Fringe-eared Oryx and Lesser kudu in the Northern Tanzania and Southern Kenya borderland after the 2007 to 2009 drought. The species were characterized by low numbers and sparsely distributed in the borderland but were more prevalent and abundant in the Amboseli region. However, West Kilimanjaro had the highest positive change in density between 2010 and 2013 [Gerenuk $=+1650.48 \pm 1150.31$, lesser kudu $=$ $+912.78 \pm 487.63$ and Fringe-eared Oryx $=+366.65 \pm 233.32]$. Changes in density and composition varied seasonally among the different sectors of the borderland, with Gerenuk having the highest change in the Amboseli area during the wet season. Lesser kudu had the highest change in Amboseli and Kilimanjaro during the wet season while Fringe-eared Oryx had the highest change in the wet season in West Kilimanjaro area. Spatial distribution of the species varied seasonally and across different sectors of the borderland. In the dry season, Gerenuk exhibited a clumped distribution mainly in Amboseli National Park, and between Natron and West Kilimanjaro but in the wet season, it spread out more though higher concentrations were still found Amboseli and West Kilimanjaro. Lesser concentrated in mostly in West Kilimanjaro and Amboseli during the dry season but was widely dispersed during the wet season. Similarly, during the dry season, the Fringe-eared Oryx was confined in the Amboseli and West Kilimanjaro areas but during the wet season, it much more spread out with clusters in the Mbirikani area of the Amboseli region and a few places in Magadi, Natron and West Kilimanjaro. Management implications of the find- 
ings obtained in this study area here-in discussed.

\section{Keywords}

Borderland, Fringe-Eared Oryx, Gerenuk, Kenya, Lesser Kudu, Population Trend and Status, Tanzania

\section{Introduction}

Since the advent of the modern wildlife conservation movement in Africa, countries in East African have tended to focus on what are considered as charismatic species such as the African elephant Loxodonta africana and black rhino Diceros bicornis, Cheetah Acinonyx jubatus and other species are to an extent given little or no attention. While this has helped halt extinction of species that are at a high risk of being exterminated, there's a danger that other species will go extinct due to lack of conservation attention. This calls for a change in the conservation strategies used by these countries failure to which many species will be lost. In this regard, this paper focuses on the Gerenuk Litocranius walleri, lesser kudu Tragelaphus imberbis and Fringe-eared Oryx Oryx beisa callotis which are among many other species that are not adequately protected; yet they are important biodiversity types. The Gerenuk occurs throughout the horn of African in southern Djibouti, Somalia and Ethiopia, Kenya and northeastern Tanzania though its status in Somalia is not well known [1]. It was once found in northeastern Sudan and eastern Egypt and northeastern Sudan, and usually inhabits thickets, bushland and semi-arid and arid thornbush [below $1600 \mathrm{~m}$ ], and avoids very open grass dominated habitats and dense woodlands [1] [2]. They are selective browsers, and seldom graze [1] and rarely drink water but obtain it from preformed water contained in the forage the feed on [3], which allows them to survive in dry landscapes.

Although the Gerenuk is widespread in its former range, including Somalia where it's severely reduced, the [4] listed it as "Near Threatened" implying that conservation interventions are needed to save it. Their estimated population in the entire Africa continent is 95,000 , with only $10 \%$ of them found in protected areas [1] [4]. [1] observed the population in Kenya declined by $50 \%$ from 1970, and the general trend is that the species is decreasing throughout its range [4]. Some of the important protected areas where stable populations of the species are found include, Mago National Park [Ethiopia], Sibiloi, Tsavo and Meru National Parks and Samburu Game Reserve [Kenya] and Mkomazi Game Reserve and Tarangire National Park Tanzania [4]. However, the population in Tsavo National Park is declining due to drought and rinderpest while that in Djibouti is considered to be small but ecologically viable [1]. Generally, key factors contributing to decline in the population of gerenuk are habitat loss, competition for forage with livestock, droughts and illegal bush meat activities [1] [4].

The Lesser kudu, Tragelaphus imberbis occurs in east Africa including countries like Somalia, South Sudan, Kenya, Uganda and Tanzania, but it's extinct in Djibouti [1] [2]

[4]. Their habitats are mostly semi-arid Acacia-Commiphora thornbush, and tend to 
avoid open areas and those with long grass [1] [2] [3], although they have been at about $1740 \mathrm{~m}$ near Mt. Kilimanjaro in Tanzania [1] [5]. It's a water independent species and primarily selective browsers, and forages on leaves and young shoots of shrubs, herbs and trees [1], and in a study in Tsavo East National Park, Kenya, [3] observed that they fed on 150 different plant species. Like the Gerenuk, the species is declining through its range due to, uncontrolled bush meat activities and trophy hunting, habitat loss due to increase in human population and the accompanying land use changes, drought and competition for forage with livestock [4]. During the mid-1990s, an outbreak of rinderpest in the eastern regions of Kenya also caused a considerable decrease in numbers [1] [4].

Lesser kudu is listed as "Near Threatened" [4], and estimated the total population in Africa is approximately 118,000 , with about $33 \%$ of them in protected areas [1]. Some of the important protected areas where the species is found include, Awash, Omo and Mago National Parks [Ethiopia], Bush National Park (Somalia), Tsavo National Park (Kenya) and Ruaha National Park and adjoining game reserves (Tanzania) [1]. Nevertheless, given the numerous threats facing the species, and the general trend of a decreasing population, there are concerns that its status will eventually be pushed to the "Threatened" category. In this regard, their conservation and long-term survival can be enhanced by improving their protection and management inside and outside the protected areas which still support large and viable populations.

Fringe-eared Oryx, Oryx beisa callotis are found entirely south of the Tana River in eastern Kenya and north-eastern Tanzania, with key populations occurring in Tsavo East National Park and the Galana Ranch region [2]. They are also found west and south to Mkomazi, Amboseli and sporadically appearing in Serengeti National Park [2], and are probably extinct in Uganda, Sudan and Eritrea [1]. They inhabit scrubland, Acacia woodlands and semi-arid grasslands [5], and are mostly common in areas with an annual rainfall of 40 to $80 \mathrm{~cm}$ [16 to 31 inches]. Predictions [4] indicated that in the near future, the species is likely to be confined in protected areas as a result of pressure associated with habitat loss and illegal poaching outside these areas. More than $80 \%$ of their diet consists of grasses but during the wet season, this is supplemented with herbs, and in the dry season, they forage on tubers and other succulent plants which provide them with water [7]. Through such strategies, they are able to survive for up to a month without drinking, although they will do so when an opportunity arises [6].

It was estimated the total population of Fringe-eared Oryx to be nearly 17,000, and about $60 \%$ of it is found inside protected areas [1], particularly in Tsavo, Kajiado and Kilifi, (Kenya) and Tarangire and Mkomazi [Tanzania]. However, the population is gradually declining trend in most of the species' current range, except in Kajiado (Kenya), Tarangire and Mkomazi (Tanzania). The major threats facing the species are, habitat loss through encroachment by human settlements, competition for pasture with livestock, and poaching for meat and hides, though it's still listed as "Vulnerable" [4]. This calls for crafting of strategies for their enhanced protection and management inside and outside protected areas.

In Kenya and Tanzania, most of the treats facing the Fringe-eared Oryx, Lesser kudu and Gerenuk are human related by another emerging threat is climate change especially 
occurrence of droughts. Although the species are ecologically adapted to living in extremely dry and water deficient regions, they might not withstand the environmental perturbation created by severe, frequent and prolonged drought conditions. Further, their current range in both countries is increasingly subjected to numerous anthropogenic changes which together with climatic changes may threaten their natural mechanisms of survival. Thus, this study evaluated the effects of the 2007 to 2009 drought on the three species in Northern Tanzania and Southern Kenya borderland.

\section{Objectives}

The overall objective of this research was to establish the post drought population size and trend of three specialized browsers after the 2009 drought in the Kenya-Tanzania borderland

The specific objectives were to:

1) Determine the population status and trend of gerenuk, fringe-eared Oryx and lesser kudu in the Kenya-Tanzania borderland.

2) Assess spatial-temporal distribution of gerenuk, fringe-eared Oryx and lesser kudu in the Kenya-Tanzania borderland.

3) Make recommendations to enhance monitoring and conservation of wildlife populations across the Kenya-Tanzania borderland.

\section{Methods and Study Site}

\subsection{The 2008 and 2009 Drought and Its Impacts in Kenya}

According to [8], drought is a deficiency in precipitation over an extended period, usually a season or more, resulting in a water shortage causing adverse impacts on vegetation, animals, and/or people. It is a normal, recurrent feature of climate that occurs in virtually all climate zones, from very wet to very dry. Drought is a temporary aberration from normal climatic conditions, thus it can vary significantly from one region to another. Drought is different than aridity, which is a permanent feature of climate in regions where low precipitation is the norm, as in a desert.

This large mammal count was done at a time when there were two severe droughts in the Kenya/Tanzania borderland [9]. For the entire country, rainfall fell below the monthly average in 8 months out of 12, or 67 percent of the time in 2008. In 2009, the number of months showing less rainfall than the long-term monthly average increased to 9 or 75 per cent of the time. In 2010, the number of rainfall deficit months decreased to 7.5 months [ 62 percent of the time], and in the first half of 2011, the number of months rose significantly to 5 out of 7 months (72 percent of the time) [8].

A drought occurred from 2008 to 2011 in Kenya with varying durations and intensities across different regions and affecting many economic sectors From 2008-2011, Kenya experienced a meteorological drought with lower than normal precipitation duration and intensities at various times, an agricultural drought with inadequate soil moisture to meet the needs of various crops in the country, a hydrological drought with deficiencies in the availability of surface and groundwater supplies over periods of time, 
and a socio-economic drought with physical water shortages affecting the health, wellbeing, and quality of life of communities across the country. The overall impact of the 2008-2011 droughts in Kenya is estimated at Ksh 968.6 billion (US \$12.1 billion). This includes Ksh 64.4 billion (US $\$ 805.6$ million) for the destruction of physical and durable assets, and Ksh 904.1 billion (US $\$ 11.3$ billion) for losses in the flows of the economy. The most affected sector was livestock (Ksh 699.3 billion), followed by agriculture (Ksh 121.1 billion). The highest values of per capita damage and losses occurred in provinces where the HDI is lowest. The economic impact of the drought is estimated to have slowed down the growth of the country's economy by an average of 2.8 percent per year [8] [9].

\subsection{Study Area}

The study area region is situated in the Southern part of Kenya, and covers an area of approximately $8797 \mathrm{Km}^{2}$ (Figure 1). It's made up of several blocks of land, mainly,

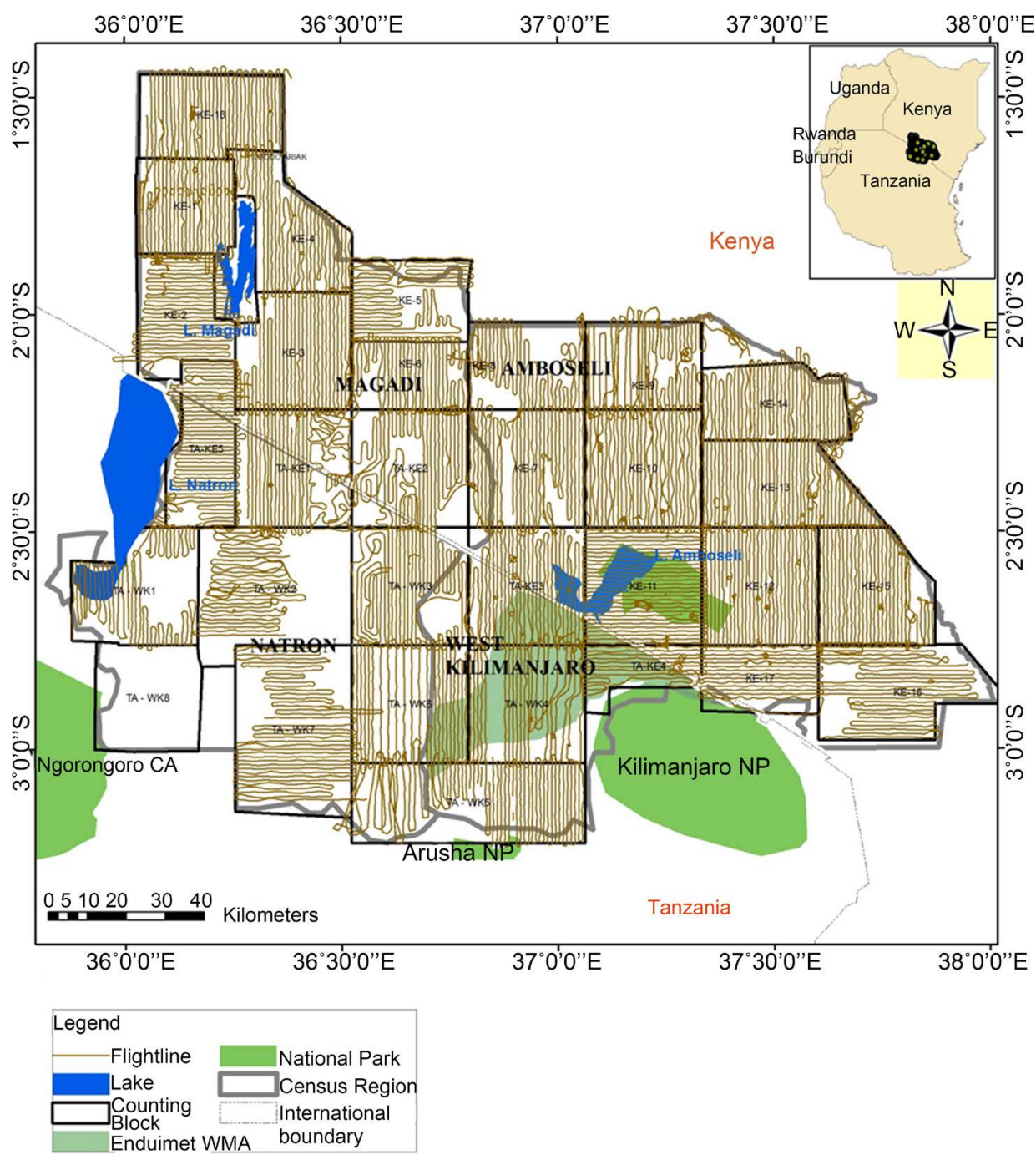

Figure 1. Layout of the census flight paths and flights paths in the study area. 
Amboseli National Park, and Maasai owned group ranches [Olgulului/Olararashi, Eselenkei/lengisim, Mbirikani, Kuku, Kaputei, Osilalei, Mailua and the former Kimana/ Tikondo Group Ranch. It also includes former 48 ranches, located on the lower slopes of Mt. Kilimanjaro along the international border with Tanzania, that are currently subdivided and under rain-fed agriculture [Figure 1]. The region consists of basement plains, saline plains with fresh water swamps and the volcanic slopes of the Mt. Kilimanjaro. Quaternary volcanic soils on the northeastern Kilimanjaro slope dominate around the southeast, which favors crop production while the southeast part of Ilkisongo is covered by basement rock soils making it largely suitable for pastoralism [10].

The Area area lies in ecological zone VI, and is generally arid to semi-arid savanna environment, with low agricultural potential [10] [11]. It's characterized by spatial and temporal variation in hydrology, and surface water is only found in few permanent streams and rivers [Figure 2]. The streams, rivers and existing water resources are predominantly a result of the hydrological influence of Mt. Kilimanjaro, where water flows underground and emerge elsewhere inform of streams, rivers or swamps [12]. These springs together with rainfall, feeds the rivers, streams and swamps in the area.

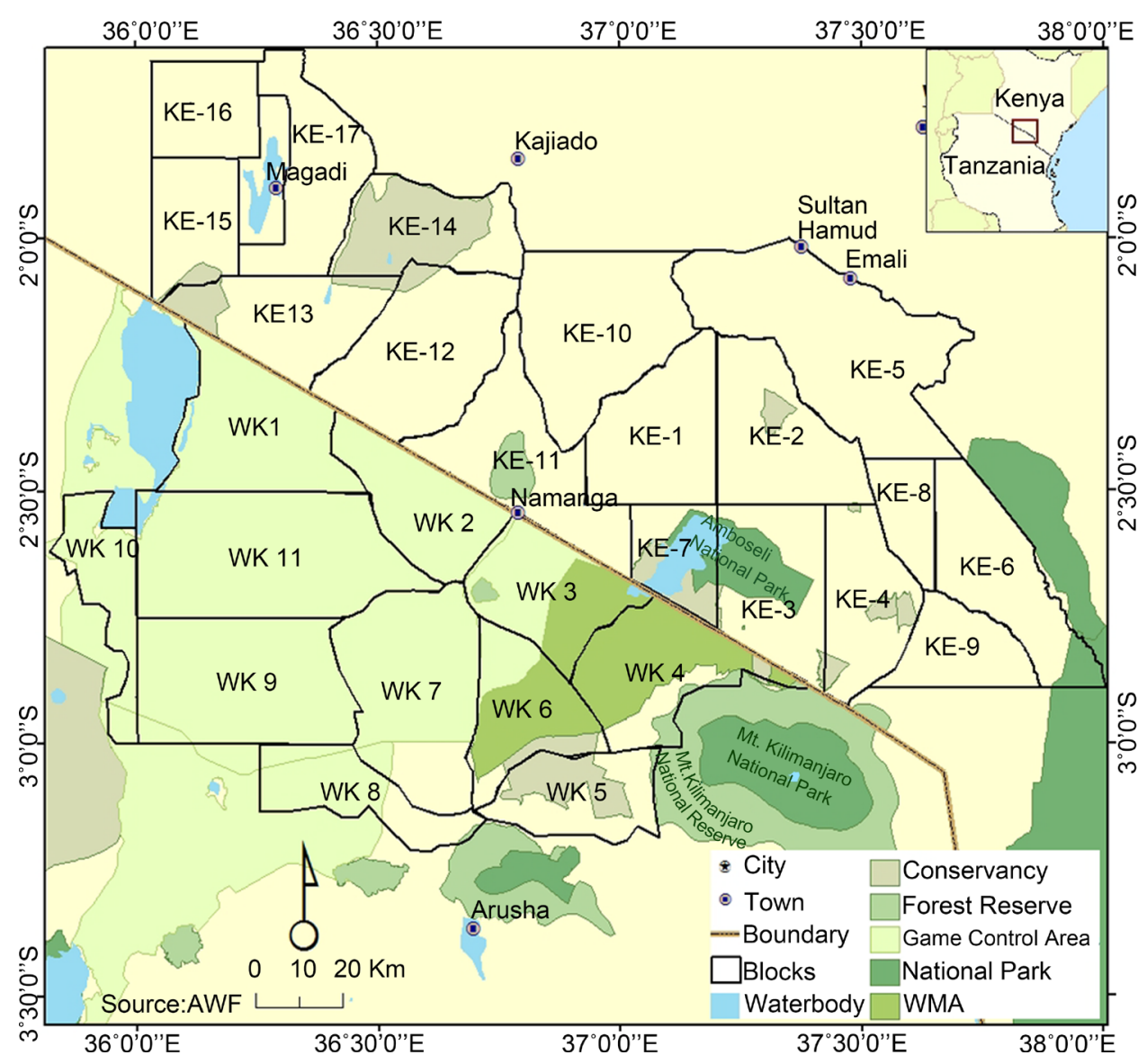

Figure 2. The Amboseli-West Kilimanjaro and Magadi-Natron landscapes along the KenyaTanzania border. 
Rainfall in the borderland region is bimodal, unpredictable and unreliable [12]. The short rains occur between the end of October and mid-December, while the long rains fall between March and May [11], and the mean annual rainfall across the area ranges from 400 to $1000 \mathrm{~mm}$ [13]. The October-December rainfall accounts for $45 \%$, and the March-May for $30 \%$ of the total rainfall, which means it's the single most important factor influencing land use practices, which currently include agriculture, pastoralism and wildlife conservation [12]. Human population growth in the region especially within the group ranches and along the slopes of Mt. Kilimanjaro has been rapid, and population in the area more than doubled between 1979 and 1999 [13]. Over the past 15 years the number of registered members within the Kimana, Kuku, and Mbirikani Group Ranches has increased by 505\%, 1323\%, and 497\%, respectively [12]. This rapid population increase is due to the immigration of non-pastoral people seeking access to more productive land within the group ranches [12]. At the same time, the land within the group ranches has experienced extensive changes over the past 30 years in response to a variety of economic, cultural, political, institutional, and demographic processes [13]. Pastoralism, which was once the backbone of the Maasai livelihood, has declined tremendously, partly as a result of increased agricultural activities that have become widespread in the entire region [12].

The vegetation of the region is typical of a semi-arid environment. Dominant vegetation types are, open grasslands towards the north and northeast to the Chyulu Hills, Acacia dominated bushland southward to the forest belt of Mt. Kilimanjaro. In these main types, there are patches of swamps and swamp-edge grasslands and Acacia woodlands [13].

\subsection{Methods}

Total aerial counts of elephants and key large herbivorous wildlife species were conducted during the dry season in 2007 [ $24^{\text {th }}$ to $29^{\text {th }}$ May at the start of rain season], 2010 [11 $1^{\text {th }}$ to $16^{\text {th }}$ October at the end of dry season] and 2013 ( $6^{\text {th }}$ to $12^{\text {th }}$ October) based on the technique by as described [14]. The count therefore employed the Global Positioning System (GPS) technique with Arc View software used for plotting species distribution maps. Counts were done within blocks demarcated based on well-defined ground features such as, roads, rivers, hills etc. (Figure 3), in an average area of $7852 \mathrm{Km}^{2}$. These features were meant to make it easier for pilots to navigate the blocks, thus the counting blocks design was demarcated so as to conform to the following rules, i) rivers were not used as boundaries of the blocks. Rivers are normally areas of concentration of animals hence not suitable as boundaries for counting blocks owing to the necessity to turn over this area and begin a new transect and the high possibility animals would move from one side of the river to the other, resulting in double counts, ii) blocks were made rectangular or square in shape, which eased navigation for the pilots and FSOs using GPS and allowed more time for observations, iii) blocks were made small enough to be counted within a maximum of six hours a day, and an area of $900 \mathrm{~km}^{2}$ was deemed a suitable average size of a block, and, iv) block boundaries did not cut across areas of high wildlife density as determined by kernel densities from previous surveys. 


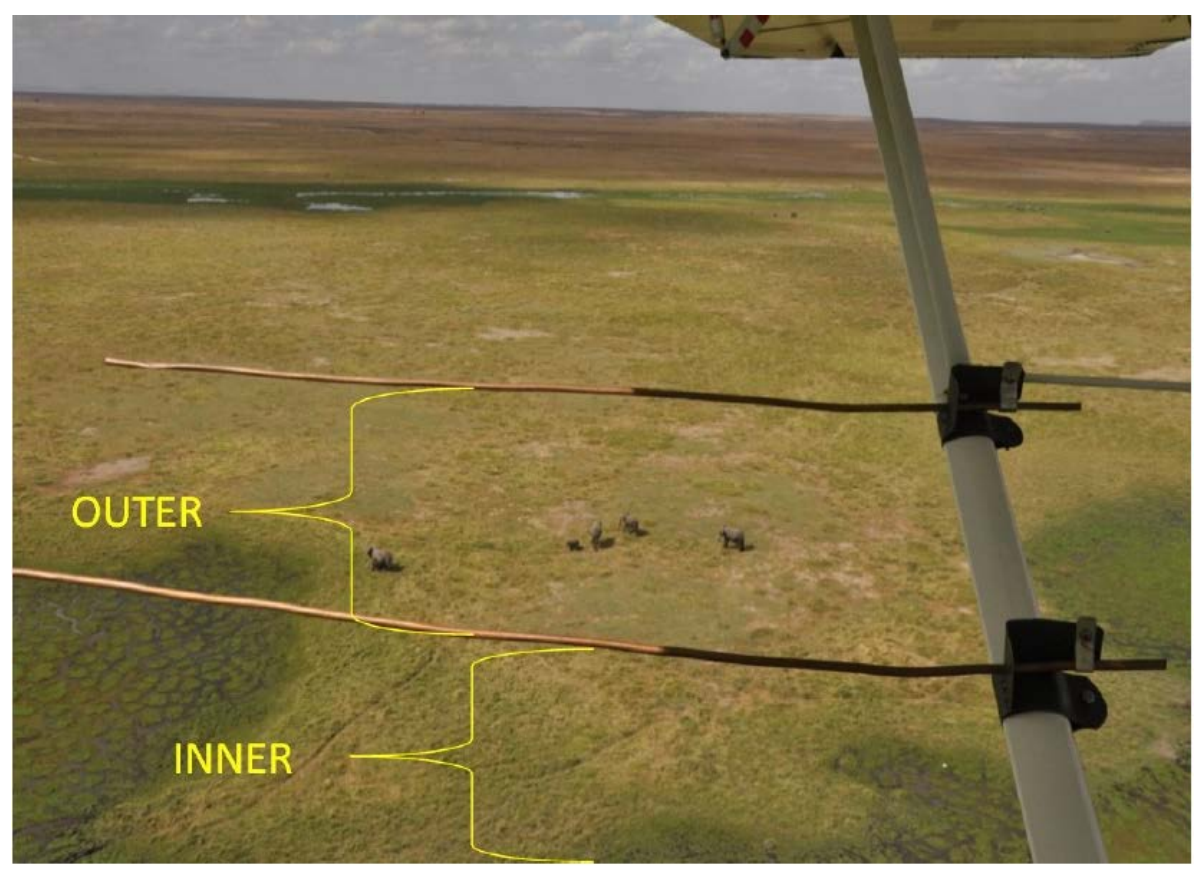

Figure 3. Position of steamers on the wings of an aircraft.

To improve the quality of data collected on wildlife populations, the crew was trained on use of various counting and estimation techniques, use of equipment (GPS), voice recorders and cameras, species identification and estimation, data handling and processing. Practical training sessions and test flights were included as rehearsal for the actual census. The test flights involved the different flight crews flying the same mock transects at different intervals while maintaining same orientation in order to assess inter observer variability in species detection, estimation and identification. Thereafter, each block was systematically searched using light air-crafts flying either North South or East West directions along transects of $1-2 \mathrm{~km}$ width depending on visibility and terrain (Figure 3). The aircraft crew consisted of a pilot, Front Seat Observer (FSO) and Rear Seat Observer (RSO). The aircraft crew systematically searched for and made observations and recording of elephants and key large wildlife species and their number along the flight transects. For each observation a waypoint was marked using a hand held Global Positioning System (GPS) and the observation recorded on a data sheet. Tape recorders were also used to aid in data capture and data were transcribed into the datasheet after every survey session. Large herds of more than 10 individuals were photographed unless the view was obstructed by thick vegetation, in order to establish the correct count [15]. At the end of each count session, the GPS flight paths and waypoints were down loaded using DNR-Garmin/MapSource software, and the Front Seat Observers (FSO) did a summary table of each block. Any double counts in neighboring blocks were also validated worked out and eliminated during these sessions. Voice records were processed digitally to remove background noises and improve the clarity. A team of data handlers transcribed the voice records onto datasheets and entered these into a digital database. The exercise started every morning at around 7.30am and ended in 
the afternoon. End time was variable because it depended on the size of the blocks, and rest breaks were taken during refueling of the aircrafts and at lunch time. Flight path and way point data were processed using ArcGIS 9.3 program, while the observation data sheets were cleaned and entered into Microsoft Excel 2003/2007 for further analysis.

\subsection{Data Analysis}

Only data for the dry period of 2007, 2010 and 2013 were used. Tallies, percentages, means and standard errors for the data were calculated using standard statistical methods [16]. Population changes were done based on the density of the 2010 and assessing as a percentage, how values varied before that year (for 2007) and how values varied after that year (2013). Chi-square cross-tabulations were done to establish the association between species numbers and the counting areas (group ranch locations), and between species numbers and years (effect of drought periods) using SPSS statistical software. Even though the dry season census area of the year 2007 was $5542 \mathrm{~km}^{2}$ mainly in Amboseli Ecosystem, the census area increased to $24,000 \mathrm{~km}^{2}$ in 2010 and further to $25,623 \mathrm{~km}^{2}$ in 2013 to cover the entire Kenya/Tanzania borderland. The total numbers may therefore be affected by the size, but the density and proportions of each species of the large mammals seen were reliable measures for comparison due to weighting per unit area and as a proportion.

\section{Results}

\subsection{Gerenuk}

The Gerenuk was poorly represented both in number and distribution in all the landscapes and ecosystems (protected areas and dispersal areas) along the Kenya-Tanzania borderland during the 2010 and 2013 censuses. Amboseli and its surrounding group ranches had the highest number of gerenuk (Table 1) in the borderland (averaging 90.3 \pm 8.7 gerenuk), followed by Lake Natron area (40.8 \pm 9.9 gerenuk), West Kilimanjaro area (26.8 \pm 14.3 gerenuk), and lastly Lake Magadi area (23.0 \pm 11.5 gerenuk).

In terms of the composition (Figure 4) of gerenuk in each area of the borderland (Figure 3), similar order was seen, with Amboseli and surrounding group ranches led $(55.18 \% \pm 8.74 \%)$ followed by Lake Natron area $(22.66 \% \pm 2.42 \%)$, West Kilimanjaro area $(11.97 \% \pm 5.03 \%)$, and lastly Magadi area $[10.18 \% \pm 4.35 \%]$. Further, in terms of gerenuk density (Figure 5), Amboseli area had a gerenuk density (Table 1) averaging $0.01 \pm 0.00$ gerenuk per $\mathrm{km}^{2}$, similar to Lake Natron area [0.01 \pm 0.00 gerenuk per $\mathrm{km}^{2}$ ] and West Kilimanjaro area $\left(0.01 \pm 0.0\right.$ gerenuk per $\left.\mathrm{km}^{2}\right)$. Lake Magadi area had the lowest gerenuk density $\left(0.00 \pm 0.00\right.$ gerenuk per $\left.\mathrm{km}^{2}\right)$.

Considering changes (percent) in the density in each of the locations of the borderland between 2010 and 2013, West Kilimanjaro area had the highest positive average percent change [increase] in gerenuk density $(+1650.48 \pm 1150.31)$, compared to other locations in the borderland (Table 2 ). The second positive growth in gerenuk density was seen in Lake Magadi area $(+1263.42 \pm 720.79)$. This was followed by Lake Natron 
Table 1. Gerenuk numbers and density in the key population hotspots of the Kenya/Tanzania borderland.

\begin{tabular}{|c|c|c|c|c|c|c|}
\hline Location & Year & Season & $\begin{array}{c}\text { Census } \\
\text { area }\left[\mathrm{km}^{2}\right]\end{array}$ & $\begin{array}{l}\text { Impala } \\
\text { numbers }\end{array}$ & $\begin{array}{c}\text { Gerenuk } \\
\text { density [per } \\
\mathrm{km}^{2} \text { ] }\end{array}$ & $\begin{array}{c}\text { Proportion [\%] } \\
\text { gerenuk numbers in } \\
\text { the borderland }\end{array}$ \\
\hline \multirow{5}{*}{$\begin{array}{c}\text { Amboseli and } \\
\text { surrounding group } \\
\text { ranches }\end{array}$} & \multirow{2}{*}{2010} & Wet & 8797.00 & 73 & 0.01 & 62.39 \\
\hline & & Dry & 8797.00 & 84 & 0.01 & 76.36 \\
\hline & \multirow{2}{*}{2013} & Wet & 9214.44 & 114 & 0.01 & 43.51 \\
\hline & & Dry & 9214.44 & 90 & 0.01 & 38.46 \\
\hline & \multicolumn{2}{|c|}{$\begin{array}{c}\text { Overall } \\
{[\text { Mean } \pm \text { SE }]}\end{array}$} & - & $90.3 \pm 8.7$ & $0.01 \pm 0.00$ & $55.18 \pm 8.74$ \\
\hline \multirow{5}{*}{$\begin{array}{c}\text { Magadi/Namanga } \\
\text { Areas }\end{array}$} & \multirow{2}{*}{2010} & Wet & 5513.00 & 5 & 0.00 & 4.27 \\
\hline & & Dry & 5513.00 & 2 & 0.00 & 1.82 \\
\hline & \multirow{2}{*}{2013} & Wet & 6348.32 & 37 & 0.01 & 14.12 \\
\hline & & Dry & 63.48 .32 & 48 & 0.01 & 20.51 \\
\hline & \multicolumn{2}{|c|}{$\begin{array}{c}\text { Overall } \\
{[\text { Mean } \pm \text { SE }]}\end{array}$} & - & $\begin{array}{c}23.0 \pm \\
11.5 \\
\end{array}$ & $0.00 \pm 0.00$ & $10.18 \pm 4.35$ \\
\hline \multirow{5}{*}{$\begin{array}{l}\text { West Kilimanjaro } \\
\text { Area }\end{array}$} & \multirow{2}{*}{2010} & Wet & 3014.00 & 11 & 0.00 & 9.40 \\
\hline & & Dry & 3014.00 & 1 & 0.00 & 0.91 \\
\hline & \multirow{2}{*}{2013} & Wet & 3013.18 & 66 & 0.02 & 25.19 \\
\hline & & Dry & 3013.18 & 29 & 0.01 & 12.39 \\
\hline & \multicolumn{2}{|c|}{$\begin{array}{c}\text { Overall } \\
{[\text { Mean } \pm \text { SE }]}\end{array}$} & - & $26.8 \pm 14.3$ & $0.01 \pm 0.00$ & $11.97 \pm 5.03$ \\
\hline \multirow{5}{*}{ Lake Natron Area } & \multirow{2}{*}{2010} & Wet & 7047.00 & 28 & 0.00 & 23.93 \\
\hline & & Dry & 7047.00 & 23 & 0.00 & 20.91 \\
\hline & \multirow{2}{*}{2013} & Wet & 7047.26 & 45 & 0.01 & 17.18 \\
\hline & & Dry & 7047.26 & 67 & 0.01 & 28.63 \\
\hline & \multicolumn{2}{|c|}{$\begin{array}{c}\text { Overall } \\
{[\text { Mean }+ \text { SE }}\end{array}$} & - & $40.8 \pm 9.9$ & $0.01 \pm 0.00$ & $22.66 \pm 2.42$ \\
\hline
\end{tabular}

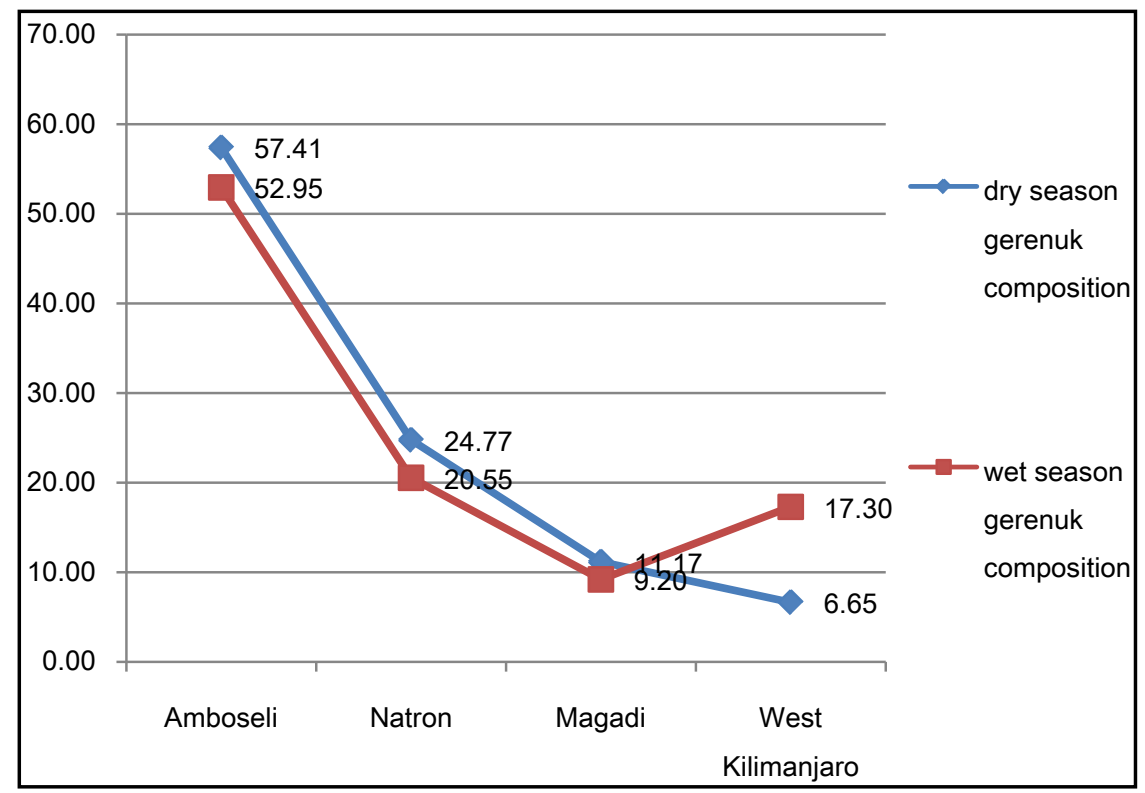

Figure 4. Gerenuk composition [\%] in the wet and dry season in the Kenya-Tanzania borderland ecosystem. 


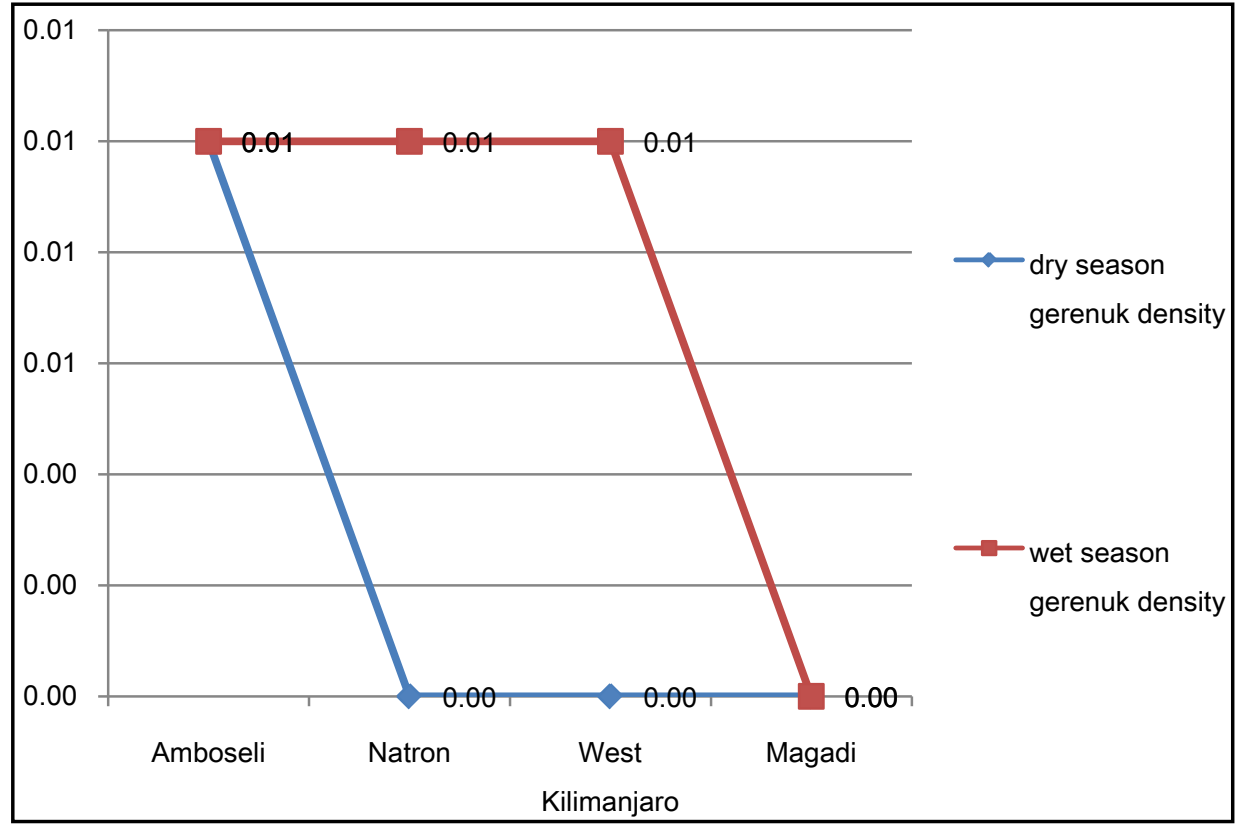

Figure 5. Gerenuk densities [per $\left.\mathrm{km}^{2}\right]$ in the wet and dry season in the Kenya-Tanzania borderland ecosystem.

Table 2. Gerenuk numbers and density changes in wet and dry seasons between 2010 and 2013.

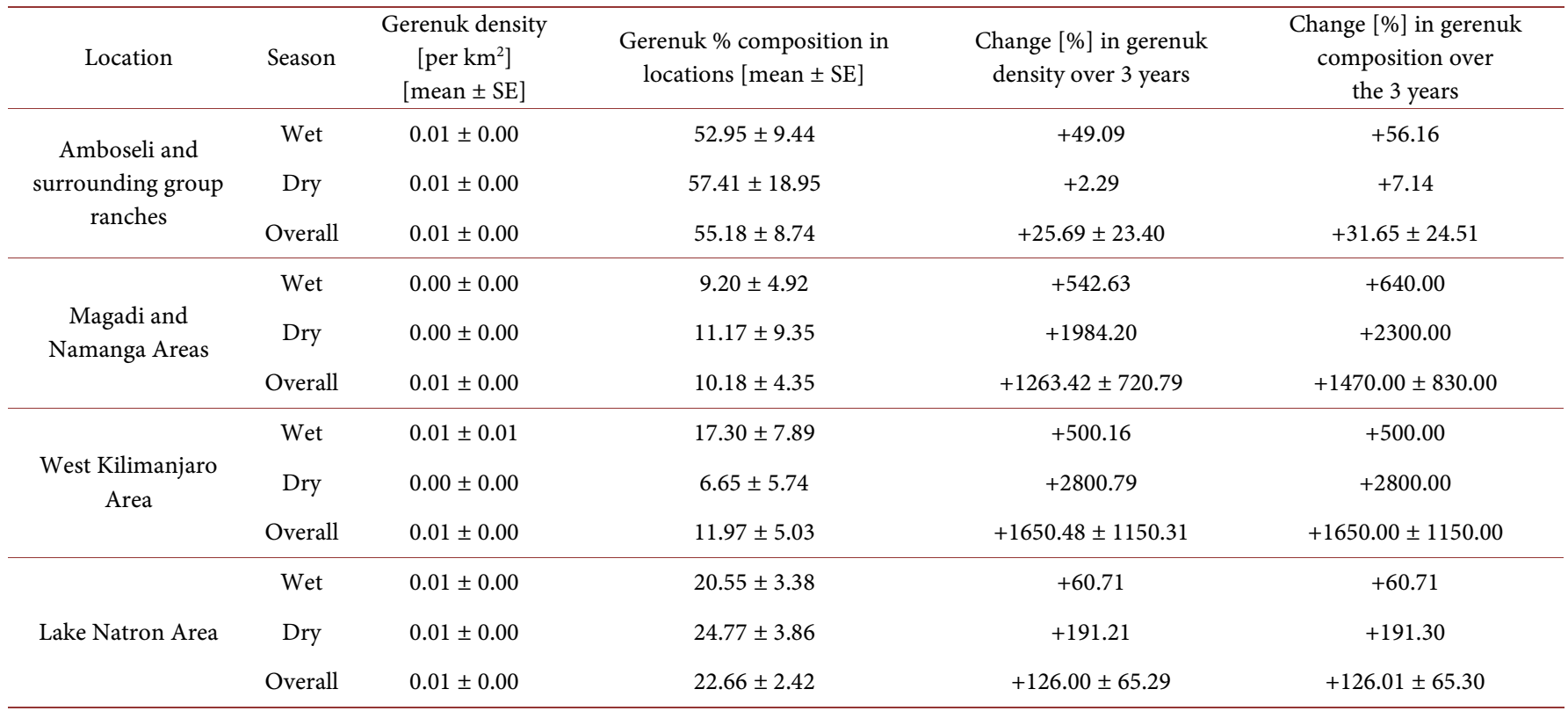

area $(+126.01 \pm 65.30)$ which has a positive growth in all seasons similar to West Kilimanjaro and Magadi areas. Amboseli and surrounding group ranches had the lowest change in gerenuk density $(+25.69 \pm 23.40)$ despite having the most number of gerenuk in the borderland. All the changes in each season were positive for all locations and all the seasons implying increase in the gerenuk density over time and from dry to wet season. 
In terms of changes (percent) in the gerenuk number composition of the locations in the borderland between 2010 and 2013, similar trend as in changes with density was observed. West Kilimanjaro area had the highest positive average percent change [increase] in gerenuk numbers $(+1650.00 \pm 1150.00)$, compared to other locations in the borderland (Table 2). The second positive growth in gerenuk numbers was also seen in Lake Magadi area $(+1470.00 \pm 830.00)$. This was followed by Lake Natron area $(+126.00$ $\pm 65.29)$ which has a positive growth in numbers in all seasons similar to West Kilimanjaro and Magadi areas. Amboseli and surrounding group ranches had also the lowest change in gerenuk numbers $(+31.65 \pm 24.51)$ despite having the most number of gerenuk in the borderland. All the changes in each season were positive for all locations and all the seasons implying increase in the gerenuk numbers over time and from dry to wet season.

There were higher wet season changes in gerenuk density and composition in Amboseli area only. However, higher dry season changes occurred in Magadi, West Kilimanjaro and Natron areas. The highest change differences in both density and composition occurred in West Kilimanjaro followed by Magadi and then Natron (Table 2).

Wet and dry season numbers over time varied from with location in the borderland (Table 3). For the Amboseli area in 2010, dry season and wet season numbers were similar ( $\mathrm{p}=38$ ), with non-significant higher number in dry than wet season. Further, for 2013, wet season and dry season number were similar $(p=0.093)$, with wet season numbers being non-significantly higher than dry season. For the set of wet season, gerenuk number in 2013 was higher ( $\mathrm{p}=0.03$ than for 2010 (i.e. gerenuk number increased with time for both seasons). However, for the set of dry season, the numbers were similar $(\mathrm{p}=0.65)$, with non-significant more numbers in 2013 in Amboseli area (Table 3).

For Magadi area for 2010, wet season and dry season gerenuk number was similar ( $p$ $=0.26$ ), with non-significant more in the wet season than dry season. Similarly for 2013, wet season and dry season gerenuk number was similar $(p=0.23)$, with nonsignificant more in the dry season than the wet season. However, for the set of wet season, and dry season, gerenuk number in 2013 was higher ( $\mathrm{p}<0.001$ in both cases) than for 2010 (i.e. gerenuk number increased with time for both seasons) in Magadi area. For West Kilimanjaro in 2010, wet season number was higher $(\mathrm{p}<0.001)$ than dry season number. Similarly for 2013 , wet season number was higher $(p<0.001)$ than dry season number. For the set of wet season, and dry season, gerenuk number in 2013 was higher ( $\mathrm{p}<0.001$ in both cases) than for 2010 (i.e. gerenuk number increased with time for both seasons) for West Kilimanjaro area (Table 3).

Lake Natron area had different outcomes when wet and dry season gerenuk numbers were compared (Table 3). For 2010, dry season and wet season gerenuk numbers were similar $(\mathrm{p}=0.48)$, with a non-significant more numbers in wet than dry season. Similarly for 2013, dry season and wet season gerenuk numbers were similar $(\mathrm{p}=0.38)$, with a non-significant more numbers in dry than wet season. But for the set of wet season ( $\mathrm{p}$ $=0.047)$, and dry season $(\mathrm{p}<0.001)$, gerenuk number in 2013 was higher than for 
Table 3. Gerenuk numbers between seasons and within season in various locations within the Kenya-Tanzania borderland.

\begin{tabular}{|c|c|c|c|c|c|}
\hline \multirow{2}{*}{$\begin{array}{l}\text { Census } \\
\text { location }\end{array}$} & \multirow{2}{*}{ Year } & \multicolumn{2}{|c|}{ Season census done } & \multirow{2}{*}{$\begin{array}{l}\text { Chi-square goodness } \\
\text { of fit value }\end{array}$} & \multirow{2}{*}{ Conclusion } \\
\hline & & Wet season & $\begin{array}{c}\text { Dry } \\
\text { season }\end{array}$ & & \\
\hline \multirow{3}{*}{ Amboseli } & 2010 & 73 & 84 & $\begin{array}{c}\mathrm{X}^{2}=0.77, \mathrm{df}=1 \\
\mathrm{p}=0.38\end{array}$ & $\begin{array}{l}\text { For 2010, dry season and wet season numbers were similar, with } \\
\text { non-significant higher number in dry than wet season. }\end{array}$ \\
\hline & 2013 & 114 & 90 & $\begin{array}{l}\mathrm{X}^{2}=2.82, \mathrm{df}=1 \\
\quad \mathrm{p}=0.093\end{array}$ & $\begin{array}{l}\text { For } 2013 \text {, wet season and dry season number were similar, with wet } \\
\text { season numbers being non-significantly higher than dry } \\
\text { season. }\end{array}$ \\
\hline & $\begin{array}{l}\text { Chi-squar } \\
\text { e value }\end{array}$ & $\begin{array}{l}\mathrm{X}^{2}=8.99 \\
\mathrm{df}=1 \\
\mathrm{p}=0.03\end{array}$ & $\begin{array}{l}\mathrm{X}^{2}=0.21 \\
\mathrm{df}=1 \\
\mathrm{p}=0.65\end{array}$ & $\begin{array}{l}\text { For the set of wet seaso } \\
\text { number increased with } \\
\text { numbers were similar, }\end{array}$ & $\begin{array}{l}\text {, gerenuk number in } 2013 \text { was higher than for } 2010 \text { [i.e. gerenuk } \\
\text { ime for both seasons]. However, for the set of dry season, the } \\
\text { ith non-significant more numbers in } 2013 \text {. }\end{array}$ \\
\hline \multirow{3}{*}{ Magadi } & 2010 & 5 & 2 & $\begin{array}{c}\mathrm{X}^{2}=1.29, \mathrm{df}=1 \\
\mathrm{p}=0.26\end{array}$ & $\begin{array}{l}\text { For } 2010 \text {, wet season and dry season gerenuk number was similar, } \\
\text { with non-significant more in the wet season than dry season. }\end{array}$ \\
\hline & 2013 & 37 & 48 & $\begin{array}{l}\mathrm{X}^{2}=1.42, \mathrm{df}=1 \\
\mathrm{p}=0.23\end{array}$ & $\begin{array}{l}\text { For 2013, wet season and dry season gerenuk number was similar, } \\
\text { with non-significant more in the dry season than the wet season. }\end{array}$ \\
\hline & $\begin{array}{l}\text { Chi-squar } \\
\text { e value }\end{array}$ & $\begin{array}{c}\mathrm{X}^{2}=24.38 \\
\mathrm{df}=1 \\
\mathrm{p}<0.001\end{array}$ & $\begin{aligned} \mathrm{X}^{2} & =42.32 \\
\mathrm{df} & =1 \\
\mathrm{p} & <0.001\end{aligned}$ & $\begin{array}{l}\text { For the set of wet seaso } \\
\text { [i.e. gerenuk number in }\end{array}$ & $\begin{array}{l}\text {, and dry season, gerenuk number in } 2013 \text { was higher than for } 2010 \\
\text { rreased with time for both seasons]. }\end{array}$ \\
\hline \multirow{3}{*}{$\begin{array}{c}\text { West } \\
\text { Kilimanjaro }\end{array}$} & 2010 & 11 & 1 & $\begin{array}{c}\mathrm{X}^{2}=8.33 \\
\mathrm{df}=1, \mathrm{p}=0.004\end{array}$ & For 2010, wet season number was higher than dry season number \\
\hline & 2013 & 66 & 29 & $\begin{array}{c}\mathrm{X}^{2}=14.41 \\
\mathrm{df}=1, \mathrm{p}<0.001\end{array}$ & For 2013, wet season number was higher than dry season number \\
\hline & $\begin{array}{l}\text { Chi-squar } \\
\text { e value }\end{array}$ & $\begin{aligned} \mathrm{X}^{2} & =39.29 \\
\mathrm{df} & =1 \\
\mathrm{p} & <0.001\end{aligned}$ & $\begin{array}{l}\mathrm{X}^{2}=26.13 \\
\mathrm{df}=1 \\
\mathrm{p}<0.001\end{array}$ & $\begin{array}{l}\text { For the set of wet seaso } \\
\text { [i.e. gerenuk number in }\end{array}$ & $\begin{array}{l}\text {, and dry season, gerenuk number in } 2013 \text { was higher than for } 2010 \\
\text { reased with time for both seasons]. }\end{array}$ \\
\hline \multirow{3}{*}{ Natron } & 2010 & 28 & 23 & $\begin{array}{c}\mathrm{X}^{2}=0.49 \\
\mathrm{df}=1, \mathrm{p}=0.48\end{array}$ & $\begin{array}{l}\text { For } 2010 \text {, dry season and wet season gerenuk numbers were } \\
\text { similar, with a non-significant more numbers in wet than dry sea- } \\
\text { son. }\end{array}$ \\
\hline & 2013 & 45 & 67 & $\begin{array}{c}\mathrm{X}^{2}=4.32 \\
\mathrm{df}=1, \mathrm{p}=0.38\end{array}$ & $\begin{array}{l}\text { For } 2013 \text {, dry season and wet season gerenuk numbers were } \\
\text { similar, with a non-significant more numbers in dry than wet } \\
\text { season. }\end{array}$ \\
\hline & $\begin{array}{l}\text { Chi-squar } \\
\text { e value }\end{array}$ & $\begin{array}{l}\mathrm{X}^{2}=3.96 \\
\mathrm{df}=1 \\
\mathrm{p}=0.047\end{array}$ & $\begin{aligned} \mathrm{X}^{2} & =21.51 \\
\mathrm{df} & =1 \\
\mathrm{p} & <0.001\end{aligned}$ & \multicolumn{2}{|c|}{$\begin{array}{l}\text { For the set of wet season, and dry season, gerenuk number in } 2013 \text { was higher than for } 2010 \\
\text { [i.e. gerenuk number increased with time for both seasons]. }\end{array}$} \\
\hline
\end{tabular}

2010 (i.e. gerenuk number increased with time for both seasons) in Lake Natron area (Table 3).

In terms relationships between gerenuk numbers in different locations [closer or further away from protected areas], influence of seasons on gerenuk numbers varied among the locations in the borderland (Table 4). In general, gerenuk numbers in locations was dependent on the season (cross tabulations, $\mathrm{p}=0.004$ ), with numbers closer and further away from protected areas being different and also wet season numbers being higher than dry season. Specifically, in the wet season, gerenuk number in locations was independent $(\mathrm{p}=0.55)$ of year, with numbers in areas closer and further away from protected areas being similar over time. But in the dry season, gerenuk number in locations both closer and further away from protected areas were dependent $(\mathrm{p}<0.001)$ of year, with numbers closer and further away from protected areas increasing over time (Table 4).

Gerenuk was distributed in specific areas in clumped numbers mainly in Amboseli 
Park and between Natron and West Kilimanjaro especially in the dry season (Figure 6). But in the wet season, the gerenuk spread much more, reaching Lake Natron, Magadi/Namanga area, even though higher concentration was in Amboseli and West Kilimanjaro area (Figure 7).

Table 4. The relationship between gerenuk numbers and census location proximity to existing protected areas [Amboseli and West Kilimanjaro] and away [Magadi and Lake Natron area] within the borderland.

\begin{tabular}{|c|c|c|c|c|c|}
\hline \multirow[b]{2}{*}{$\begin{array}{l}\text { Season of } \\
\text { the year }\end{array}$} & \multirow[b]{2}{*}{ Year } & \multicolumn{2}{|c|}{ Location of census area } & \multirow{2}{*}{$\begin{array}{l}\text { Chi-square } \\
\text { cross } \\
\text { tabulation } \\
\text { value }\end{array}$} & \multirow[b]{2}{*}{ Conclusion } \\
\hline & & $\begin{array}{c}\text { In or around } \\
\text { protected areas }\end{array}$ & $\begin{array}{c}\text { Away from } \\
\text { protected areas }\end{array}$ & & \\
\hline $\begin{array}{l}\text { Wet } \\
\text { season } \\
\text { Dry } \\
\text { season }\end{array}$ & & 204 & 140 & $\begin{array}{l}\mathrm{X}^{2}=8.47 \\
\mathrm{df}=1 \\
\mathrm{p}=0.004\end{array}$ & $\begin{array}{l}\text { Generally, gerenuk numbers in locations was dependent on the } \\
\text { season, with numbers closer and further away from protected areas } \\
\text { being different and also wet season numbers being higher than dry } \\
\text { season. }\end{array}$ \\
\hline
\end{tabular}

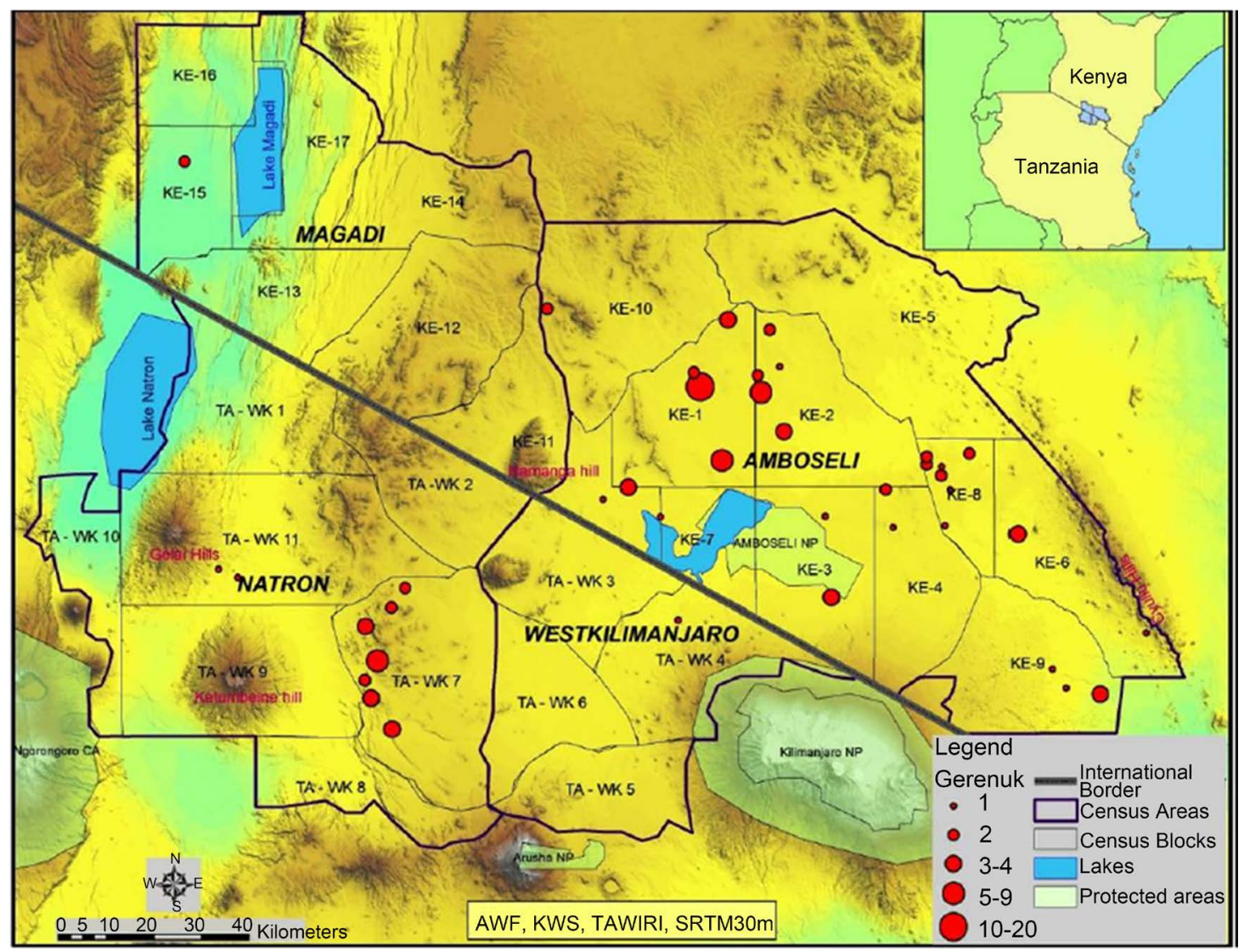

Figure 6. Gerenuk distribution in the Kenya-Tanzania borderland during the 2010 dry season census. 


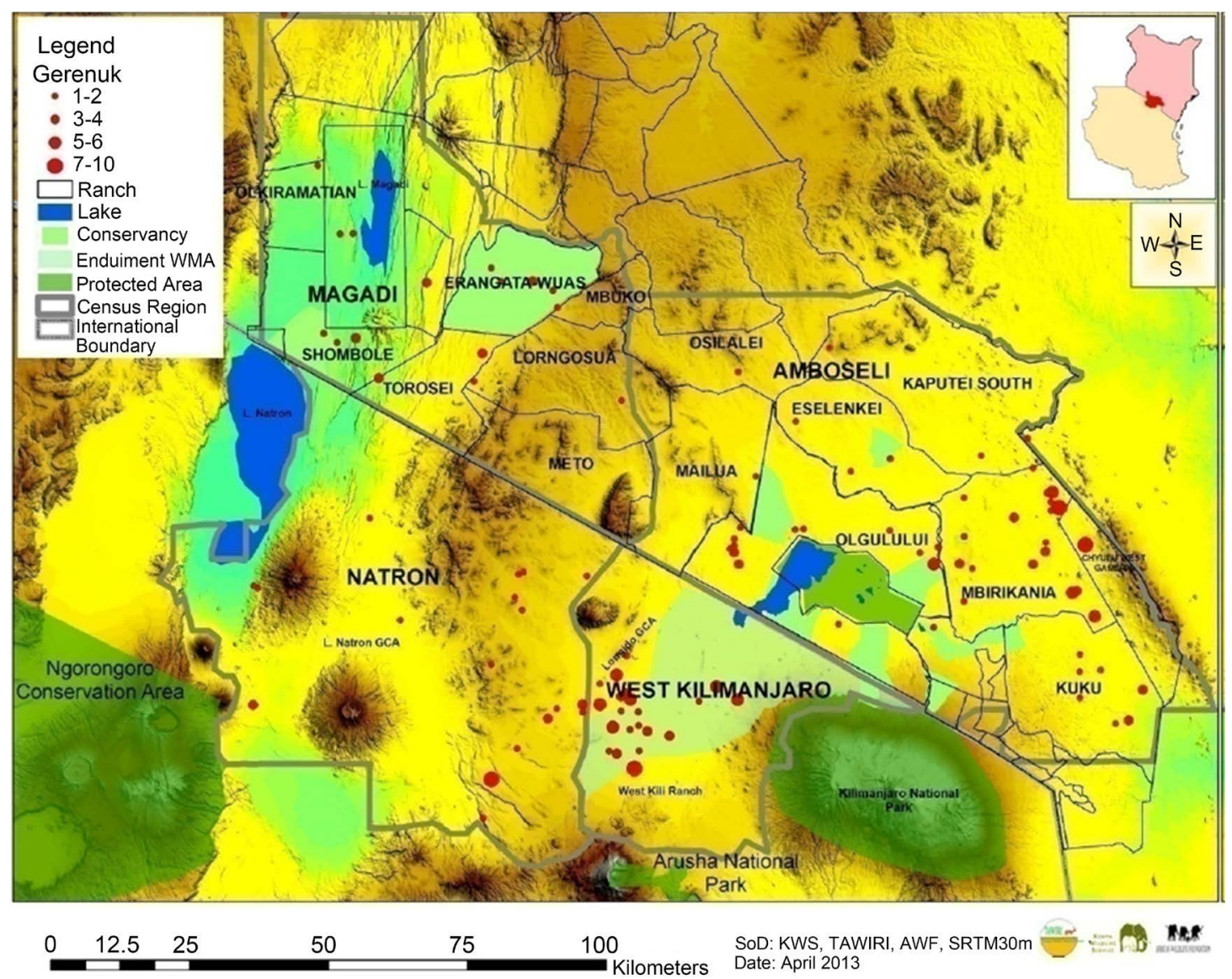

Figure 7. Gerenuk distribution in the Kenya-Tanzania borderland during the 2013 wet season census.

\subsection{Lesser Kudu}

This species was poorly represented both in number and distribution in all the landscapes and ecosystems (protected areas and dispersal areas) along the Kenya-Tanzania borderland during the 2010 and 2013 censuses. Amboseli and its surrounding group ranches had the highest number of lesser kudu (Table 5) in the borderland (averaging $90.3 \pm 8.7$ lesser kudu), followed by West Kilimanjaro area (22.3 \pm 13.2 lesser kudu), Lake Magadi area $(15.5 \pm 9.3$ lesser kudu) and lastly Lake Natron area $(9.0 \pm 3.0$ lesser kudu).

In terms of the composition (Figure 8) of lesser kudu in each area of the borderland (Figure 3), Amboseli and surrounding group ranches led [53.39\% $\pm 9.28 \%]$ followed by West Kilimanjaro area $(20.72 \% \pm 2.83 \%)$, Lake Natron area $[14.28 \% \pm 5.43 \%]$, and lastly Magadi area $(11.61 \% \pm 8.15 \%)$. Further, in terms of lesser kudu density, West Kilimanjaro area had a lesser kudu density of $0.01 \pm 0.00$ lesser kudu per $\mathrm{km}^{2}$. Other remaining areas had similar density (Table 5), with Amboseli area having a density of $\left(0.00 \pm 0.00\right.$ lesser kudu per $\left.\mathrm{km}^{2}\right)$ similar to Magadi area $(0.00 \pm 0.0$ lesser kudu per $\left.\mathrm{km}^{2}\right)$ and Lake Natron area $\left(0.00 \pm 0.00\right.$ lesser kudu per $\left.\mathrm{km}^{2}\right)$.

Considering changes (percent) in the density in each of the locations of the borderland between 2010 and 2013, West Kilimanjaro area had the highest positive average 
Table 5. Lesser kudu numbers and density in the key population hotspots of the Kenya/Tanzania borderland.

\begin{tabular}{|c|c|c|c|c|c|c|}
\hline Location & Year & Season & $\begin{array}{c}\text { Census } \\
\text { area }\left[\mathrm{km}^{2}\right]\end{array}$ & $\begin{array}{l}\text { Grant's gazelle } \\
\text { numbers }\end{array}$ & $\begin{array}{l}\text { Lesser kudu } \\
\text { density } \\
{\left[\text { per } \mathrm{km}^{2}\right]}\end{array}$ & $\begin{array}{c}\text { Proportion [\%] } \\
\text { lesser kudu } \\
\text { numbers in the } \\
\text { borderland }\end{array}$ \\
\hline \multirow{5}{*}{$\begin{array}{l}\text { Amboseli and } \\
\text { surrounding } \\
\text { group ranches }\end{array}$} & \multirow{2}{*}{2010} & Wet & 8797.00 & 10 & 0.00 & 50.00 \\
\hline & & Dry & 8797.00 & 21 & 0.00 & 77.78 \\
\hline & \multirow{2}{*}{2013} & Wet & 9214.44 & 112 & 0.01 & 53.08 \\
\hline & & Dry & 9214.44 & 35 & 0.00 & 32.71 \\
\hline & \multicolumn{2}{|c|}{$\begin{array}{c}\text { Overall } \\
{[\text { Mean } \pm \text { SE }]}\end{array}$} & - & $44.5 \pm 23.1$ & $0.00 \pm 0.00$ & $53.39 \pm 9.28$ \\
\hline \multirow{5}{*}{$\begin{array}{c}\text { Magadi/Namanga } \\
\text { Areas }\end{array}$} & \multirow{2}{*}{2010} & Wet & 5513.00 & 0 & 0.00 & 0.00 \\
\hline & & Dry & 5513.00 & 0 & 0.00 & 0.00 \\
\hline & \multirow{2}{*}{2013} & Wet & 6348.32 & 25 & 0.00 & 11.85 \\
\hline & & Dry & 63.48 .32 & 37 & 0.01 & 34.58 \\
\hline & \multicolumn{2}{|c|}{$\begin{array}{c}\text { Overall } \\
{[\text { Mean } \pm \text { SE }]}\end{array}$} & - & $15.5 \pm 9.3$ & $0.00 \pm 0.00$ & $11.61 \pm 8.15$ \\
\hline \multirow{5}{*}{$\begin{array}{c}\text { West Kilimanjaro } \\
\text { Area }\end{array}$} & \multirow{2}{*}{2010} & Wet & 3014.00 & 4 & 0.00 & 20.00 \\
\hline & & Dry & 3014.00 & 4 & 0.00 & 14.81 \\
\hline & \multirow{2}{*}{2013} & Wet & 3013.18 & 60 & 0.02 & 28.44 \\
\hline & & Dry & 3013.18 & 21 & 0.01 & 19.63 \\
\hline & \multicolumn{2}{|c|}{$\begin{array}{c}\text { Overall } \\
{[\text { Mean } \pm \text { SE }]}\end{array}$} & - & $22.3 \pm 13.2$ & $0.01 \pm 0.00$ & $20.72 \pm 2.83$ \\
\hline \multirow{5}{*}{ Lake Natron Area } & \multirow{2}{*}{2010} & Wet & 7047.00 & 6 & 0.00 & 30.00 \\
\hline & & Dry & 7047.00 & 2 & 0.00 & 7.41 \\
\hline & \multirow{2}{*}{2013} & Wet & 7047.26 & 14 & 0.00 & 6.64 \\
\hline & & Dry & 7047.26 & 14 & 0.00 & 13.08 \\
\hline & \multicolumn{2}{|c|}{$\begin{array}{c}\text { Overall } \\
{[\text { Mean } \pm \text { SE }]}\end{array}$} & - & $9.0 \pm 3.0$ & $0.00 \pm 0.00$ & $14.28 \pm 5.43$ \\
\hline
\end{tabular}

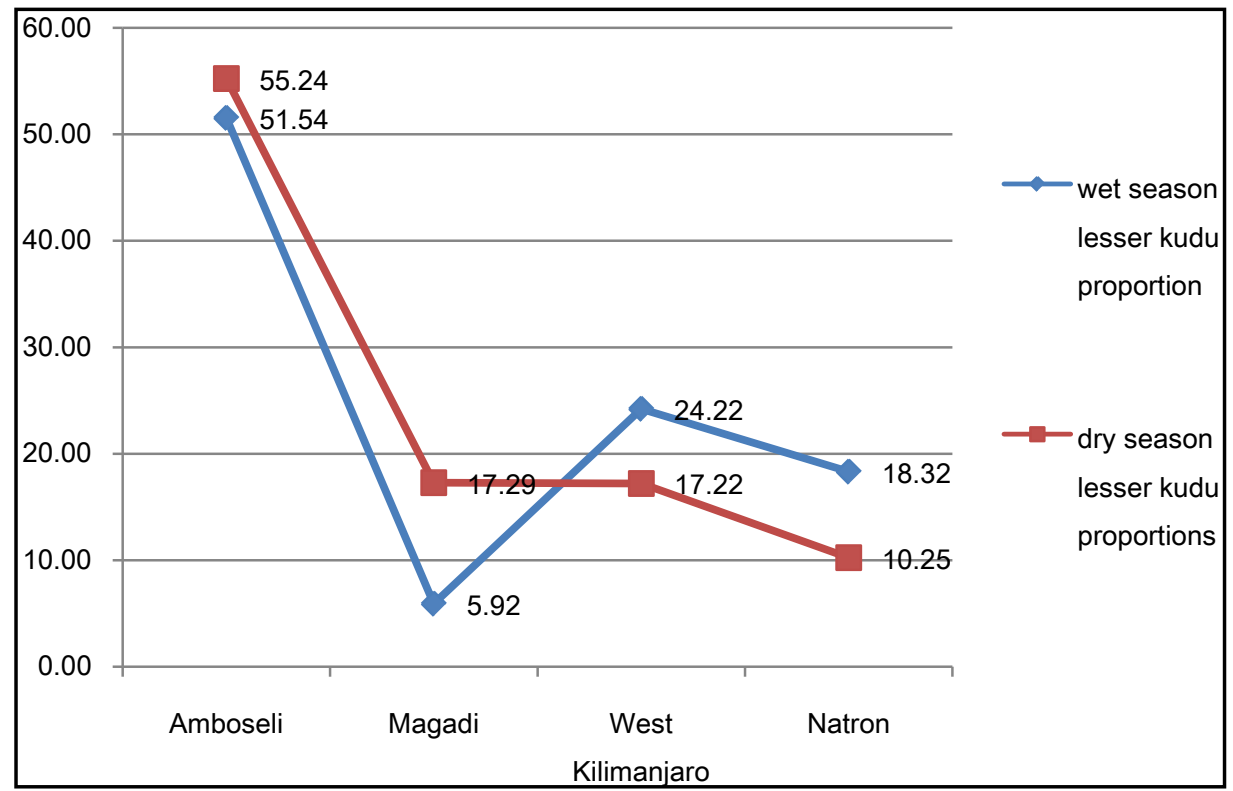

Figure 8. Lesser kudu proportions [\%] in the wet and dry season in the Kenya-Tanzania borderland. 
percent change (increase) in lesser kudu density ( $+912.78 \pm 487.63)$, compared to other locations in the borderland [Table 6]. The second positive growth in lesser kudu density was seen in Amboseli area $(+514.19 \pm 455.07)$. This was followed by Lake Natron area $(+366.65 \pm 233.32)$ which has a positive growth in all seasons similar to West Kilimanjaro and Amboseli areas. Magadi/Namanga and surrounding areas had no lesser kudu counted in 2010, and therefore the change in Oryx density could not be determined. However, the fact that it was seen in 2013 implies a positive growth in density over time. All the changes in each season were positive for all locations and all the seasons implying increase in the lesser kudu density over time and from dry to wet season (Table 6).

In terms of changes (percent) in the lesser kudu number composition of the locations in the borderland between 2010 and 2013, similar trend as in changes with density was observed. West Kilimanjaro area had the highest positive average percent change (increase) in lesser kudu numbers $(+912.50 \pm 487.50)$, compared to other locations in the borderland (Table 6). The second positive growth in lesser kudu numbers was also seen in Amboseli area $(+543.33 \pm 476.67)$. This was followed by Lake Natron area $(+366.67$ \pm 233.33 ) which has a positive growth in all seasons similar to West Kilimanjaro and Amboseli areas. Magadi/Namanga and surrounding areas had lesser kudu counted in 2010, and therefore the change in Oryx numbers could not be determined (Table 6).

Table 6. Lesser kudu numbers and density changes in wet and dry seasons between 2010 and 2013.

\begin{tabular}{|c|c|c|c|c|c|}
\hline Location & Season & $\begin{array}{c}\text { Lesser kudu } \\
\text { density } \\
{[\text { per km²] }} \\
{[\text { mean } \pm \mathrm{SE}]}\end{array}$ & $\begin{array}{c}\text { Lesser } \\
\text { kudu \% } \\
\text { numbers in } \\
\text { location } \\
{[\text { mean } \pm \mathrm{SE}]}\end{array}$ & $\begin{array}{l}\text { Change [\%] in } \\
\text { lesser kudu } \\
\text { density over } 3 \\
\text { years }\end{array}$ & $\begin{array}{l}\text { Change [\%] in } \\
\text { lesser kudu } \\
\text { proportion over } \\
\text { the } 3 \text { years }\end{array}$ \\
\hline \multirow{3}{*}{$\begin{array}{l}\text { Amboseli and } \\
\text { surrounding } \\
\text { group ranches }\end{array}$} & Wet & $0.01 \pm 0.01$ & $51.54 \pm 1.54$ & +969.26 & +1020.00 \\
\hline & Dry & $0.00 \pm 0.00$ & $55.24 \pm 22.53$ & +59.12 & +66.67 \\
\hline & Overall & $0.00 \pm 0.00$ & $53.39 \pm 9.28$ & $+514.19 \pm 455.07$ & $+543.33 \pm 476.67$ \\
\hline \multirow{3}{*}{$\begin{array}{c}\text { Magadi and } \\
\text { Namanga } \\
\text { Areas }\end{array}$} & Wet & $0.00 \pm 0.00$ & $5.92 \pm 5.92$ & $\begin{array}{c}\text { No animals in } \\
2010\end{array}$ & - \\
\hline & Dry & $0.00 \pm 0.00$ & $17.29 \pm 17.29$ & $\begin{array}{c}\text { No animals in } \\
2010\end{array}$ & - \\
\hline & Overall & $0.00 \pm 0.00$ & $11.61 \pm 8.15$ & $\begin{array}{c}\text { No animals in } \\
2010\end{array}$ & - \\
\hline \multirow{3}{*}{$\begin{array}{c}\text { West } \\
\text { Kilimanjaro } \\
\text { Area }\end{array}$} & Wet & $0.01 \pm 0.01$ & $24.22 \pm 4.22$ & +1400.41 & +1400.00 \\
\hline & Dry & $0.00 \pm 0.00$ & $17.22 \pm 2.41$ & +425.14 & +425.00 \\
\hline & Overall & $0.01 \pm 0.00$ & $20.72 \pm 2.83$ & $+912.78 \pm 487.63$ & $+912.50 \pm 487.50$ \\
\hline \multirow{3}{*}{$\begin{array}{c}\text { Lake Natron } \\
\text { Area }\end{array}$} & Wet & $0.00 \pm 0.00$ & $18.32 \pm 11.68$ & +133.32 & +133.33 \\
\hline & Dry & $0.00 \pm 0.00$ & $10.25 \pm 2.84$ & +599.97 & +600.00 \\
\hline & Overall & $0.00 \pm 0.00$ & $14.28 \pm 5.43$ & $+366.65 \pm 233.32$ & $+366.67 \pm 233.33$ \\
\hline
\end{tabular}


There were higher wet season changes in lesser kudu density and composition in Amboseli and West Kilimanjaro areas. But higher changes in the dry season occurred in Lake Natron area only. The highest change differences in both density and composition occurred in West Kilimanjaro, followed by Amboseli and lastly Lake Natron (Table 6).

Wet and dry season numbers over time varied from with location in the borderland (Table 7). For Amboseli area and the surrounding area in 2010, the dry season number was higher $[p=0.048]$ than wet season number. Similarly for 2013, the wet season number was higher than the wet season number. For the set of wet season, 2013 numbers were higher $(\mathrm{p}<0.001)$ than 2010 (i.e. lesser kudu numbers were increasing with time). However, the lesser kudu numbers were similar $(\mathrm{p}=0.06)$ for the set of dry season numbers, although had increased insignificantly with time in the Amboseli area (Table 7). For Magadi/Namanga area in 2010, no lesser kudu were seen. However for 2013, dry season number and wet season numbers were similar $(\mathrm{p}=0.13)$, even though dry season numbers were insignificantly higher. No comparisons for pairs of wet and

Table 7. The differences in lesser kudu numbers between seasons and within season in various locations within the Kenya-Tanzania borderland.

\begin{tabular}{|c|c|c|c|c|c|}
\hline \multirow{2}{*}{ Census location } & \multirow{2}{*}{ Year } & \multicolumn{2}{|c|}{ Season census done } & \multirow{2}{*}{$\begin{array}{l}\text { Chi-square goodness } \\
\text { of fit value }\end{array}$} & \multirow{2}{*}{ Conclusion } \\
\hline & & Wet season & Dry season & & \\
\hline \multirow{3}{*}{ Amboseli } & 2010 & 10 & 21 & $\begin{array}{l}\mathrm{X}^{2}=3.90, \mathrm{df}=1 \\
\mathrm{p}=0.048\end{array}$ & $\begin{array}{l}\text { For } 2010 \text {, dry season number was higher than } \\
\text { wet season number. }\end{array}$ \\
\hline & 2013 & 112 & 35 & $\begin{array}{c}\mathrm{X}^{2}=40.33, \mathrm{df}=1 \\
\mathrm{p}<0.001\end{array}$ & $\begin{array}{l}\text { For } 2013 \text {, wet season number was higher than } \\
\text { the wet season number. }\end{array}$ \\
\hline & $\begin{array}{l}\text { Chi-square } \\
\text { value }\end{array}$ & $\begin{array}{c}\mathrm{X}^{2}=85.28, \mathrm{df}=1 \\
\mathrm{p}<0.001\end{array}$ & $\begin{array}{c}\mathrm{X}^{2}=3.50, \mathrm{df}=1 \\
\mathrm{p}=0.06\end{array}$ & \multicolumn{2}{|c|}{$\begin{array}{l}\text { For the set of wet season, } 2013 \text { numbers were higher than } 2010 \text { [i.e. } \\
\text { Lesser kudu numbers were increasing with time]. However, the lesser } \\
\text { kudu numbers were similar for the set of dry season numbers, } \\
\text { although had increased insignificantly with time. }\end{array}$} \\
\hline \multirow{3}{*}{ Magadi } & 2010 & No animals seen & No animals seen & - & $\begin{array}{l}\text { For 2010, no lesser kudu were seen in Magadi } \\
\text { in } 2010\end{array}$ \\
\hline & 2013 & 25 & 37 & $\begin{array}{c}\mathrm{X}^{2}=2.32, \mathrm{df}=1 \\
\quad \mathrm{p}=0.13\end{array}$ & $\begin{array}{l}\text { For 2013, dry season number and wet season } \\
\text { numbers were similar, even though dry } \\
\text { season numbers were insignificantly higher. }\end{array}$ \\
\hline & $\begin{array}{l}\text { Chi-square } \\
\text { value }\end{array}$ & $\begin{array}{l}\text { Animals only seen } \\
\text { in wet season } 2013\end{array}$ & $\begin{array}{l}\text { Animals only seen } \\
\text { in dry season } 2013\end{array}$ & \multicolumn{2}{|c|}{ Animals only seen in 2013 and not anytime in 2010.} \\
\hline \multirow{3}{*}{ West Kilimanjaro } & 2010 & 4 & 4 & $\begin{array}{c}\mathrm{X}^{2}=0.000, \mathrm{df}=1 \\
\mathrm{p}=1.00\end{array}$ & $\begin{array}{l}\text { For 2010, wet season and dry season lesser } \\
\text { kudu numbers seen were exactly the same. }\end{array}$ \\
\hline & 2013 & 60 & 21 & $\begin{array}{c}\mathrm{X}^{2}=18.78, \mathrm{df}=1 \\
\mathrm{p}<0.001\end{array}$ & $\begin{array}{l}\text { For 2013, wet season number was higher than } \\
\text { dry season number }\end{array}$ \\
\hline & $\begin{array}{l}\text { Chi-square } \\
\text { value }\end{array}$ & $\begin{array}{c}\mathrm{X}^{2}=49.00, \mathrm{df}=1 \\
\mathrm{p}<0.001\end{array}$ & $\begin{array}{c}\mathrm{X}^{2}=11.56, \mathrm{df}=1 \\
\mathrm{p}<0.001\end{array}$ & \multicolumn{2}{|c|}{$\begin{array}{l}\text { For the set of wet season, and dry season, Lesser kudu number in } 2013 \\
\text { was higher than for } 2010 \text { [i.e. Lesser kudu number was increasing with } \\
\text { time in both seasons]. }\end{array}$} \\
\hline \multirow{3}{*}{ Natron } & 2010 & 6 & 2 & $\begin{array}{c}\mathrm{X}^{2}=2.00, \mathrm{df}=1 \\
\quad \mathrm{p}=0.16\end{array}$ & $\begin{array}{l}\text { For 2010, wet season and dry season numbers } \\
\text { were similar, with insignificantly more } \\
\text { numbers in the wet season. }\end{array}$ \\
\hline & 2013 & 14 & 14 & $\begin{array}{c}X^{2}=0.000, d f=1 \\
\quad p=1.00\end{array}$ & $\begin{array}{l}\text { For 2013, wet season and dry season lesser } \\
\text { kudu numbers seen were exactly the same }\end{array}$ \\
\hline & $\begin{array}{l}\text { Chi-square } \\
\text { value }\end{array}$ & $\begin{array}{l}\mathrm{X}^{2}=3.2, \mathrm{df}=1 \\
\quad \mathrm{p}=0.074\end{array}$ & $\begin{array}{c}\mathrm{X}^{2}=9.00, \mathrm{df}=1 \\
\mathrm{p}=0.003\end{array}$ & \multicolumn{2}{|c|}{$\begin{array}{l}\text { For the set of wet season, lesser kudu numbers were similar, with a } \\
\text { non-significant increase over time. However, for the set of dry season, } \\
\text { lesser kudu number in } 2013 \text { was higher than for } 2010 \text { [i.e. Lesser kudu } \\
\text { number was increasing with time in the dry season]. }\end{array}$} \\
\hline
\end{tabular}


dry season were possible as lesser kudu were only seen in 2013 in Magadi/Namanga area (Table 7).

For West Kilimanjaro area in 2010, wet season and dry season lesser kudu numbers seen were exactly the same $[\mathrm{p}=1.00]$. However for 2013 , wet season number was higher $(p<0.001)$ than dry season number. For the set of wet season, and dry season, lesser kudu number in 2013 was higher ( $\mathrm{p}<0.001$ in all cases) than for 2010 (i.e. lesser kudu number was increasing with time in both seasons) in West Kilimanjaro (Table 7). For Natron area in 2010, wet season and dry season numbers were similar $(p=0.16)$, with insignificantly more numbers in the wet season. Similarly, for 2013, wet season and dry season lesser kudu numbers seen were exactly the same $(\mathrm{p}=1.00)$. For the set of wet season, lesser kudu numbers were similar $(\mathrm{p}=0.074)$, with a non-significant increase over time. However, for the set of dry season, lesser kudu number in 2013 was higher ( $p$ $=0.003$ ) than for 2010 ([i.e. lesser kudu number was increasing with time in the dry season) in Lake Natron area (Table 7).

In terms relationships between lesser kudu numbers in different locations (closer or further away from protected areas), influence of seasons on lesser kudu numbers varied among the locations in the borderland (Table 8). Generally, lesser kudu numbers in all locations was dependent (cross tabulations, $\mathrm{p}=0.001$ ) on the season, with numbers closer as well as further away from protected areas being higher in the wet season. However, in the wet season, lesser kudu numbers in locations was independent ( $\mathrm{p}=$ 0.21 ) of year, with numbers closer and further away being similar over time. But in the dry season, lesser kudu numbers in locations was dependent $(\mathrm{p}<0.001)$ on the season, with numbers closer and further away from protected areas increasing with time.

Lesser kudu were distributed in specific areas in clumped numbers in only two places in Amboseli area and one place in West Kilimanjaro in the dry season (Figure 9). But in the wet season, the lesser kudu spread much more, reaching Namanga area from Amboseli and West Kilimanjaro areas (Figure 10).

Table 8. The relationship between lesser kudu numbers and census location proximity to existing protected areas [Amboseli and West Kilimanjaro] and away [Magadi and Lake Natron area] within the borderland.

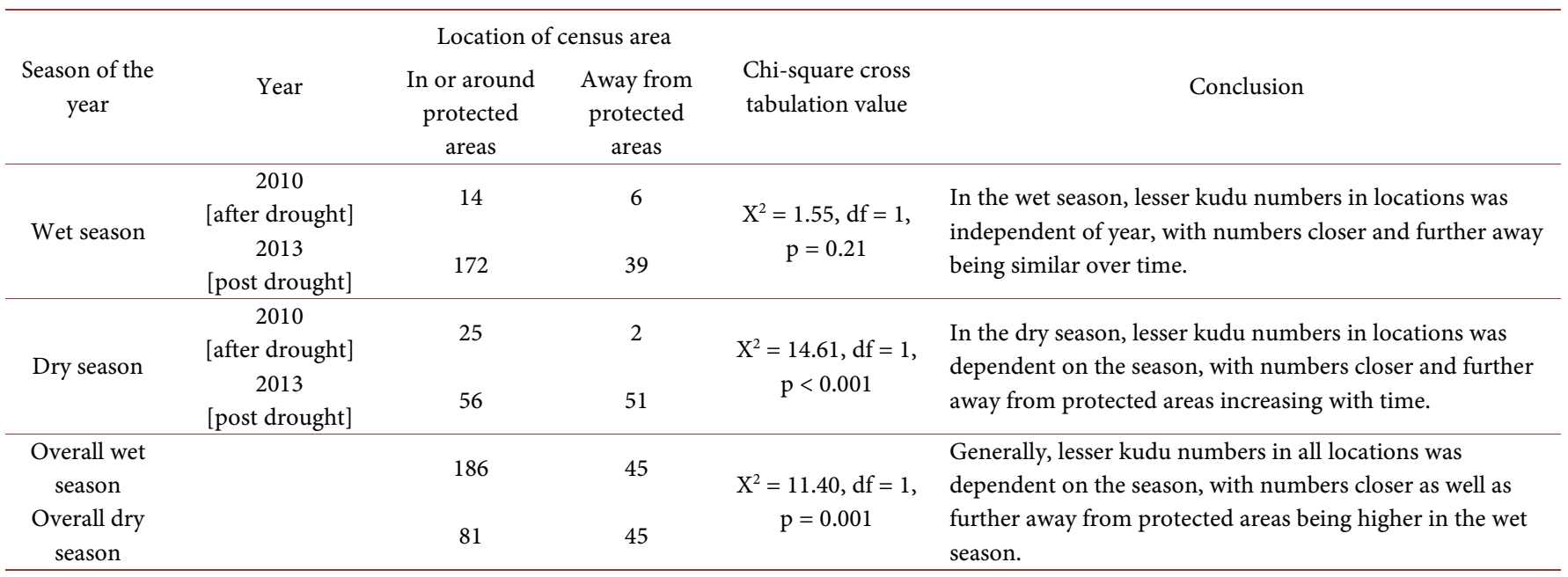




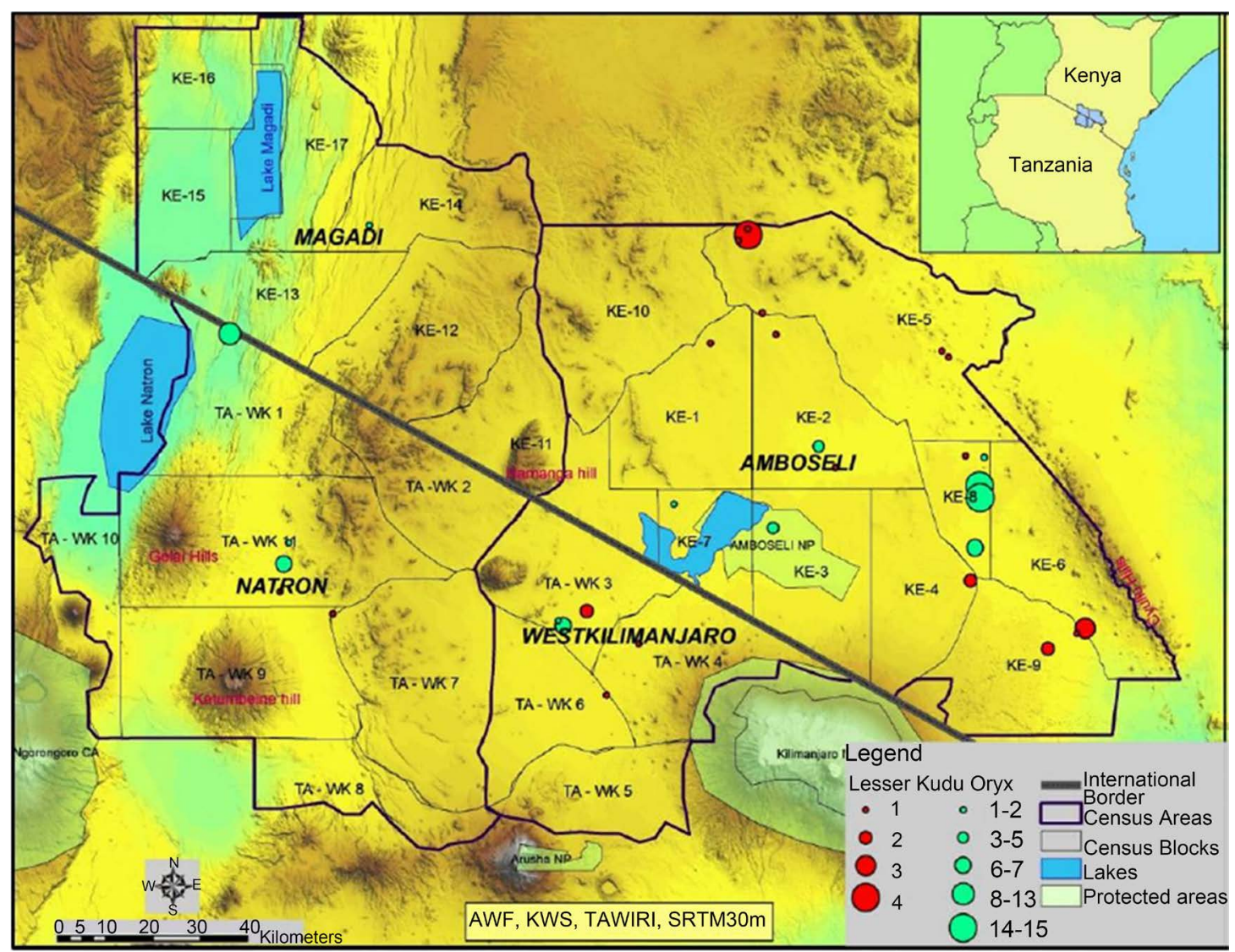

Figure 9. Lesser kudu and fringe-eared Oryx distribution in the Kenya-Tanzania borderland during the 2010 dry season census.

\subsection{Fringe-Eared Oryx}

Fringe-eared Oryx was poorly represented in number and distribution in all the locations of the Kenya-Tanzania borderland during the 2010 and 2013 censuses. Amboseli and its surrounding group ranches had the highest number of Oryx (Table 9) in the borderland (averaging $135.8 \pm 30.6$ Oryx), followed by Magadi/Namanga area (57.3 \pm 44.8 Oryx), West Kilimanjaro area $(37.3 \pm 18.1$ Oryx), and lastly Lake Natron area (32.0 \pm 19.5 Oryx).

In terms of the composition of Oryx in each area of the borderland (Figure 11), similar order was seen (Table 10), in which Amboseli and surrounding group ranches led (Figure 11) in compositiion $(60.16 \% \pm 10.39 \%)$ followed by Magadi/Namanga area $(13.79 \% \pm 7.72 \%)$, West Kilimanjaro area $(13.50 \% \pm 5.73 \%)$, and lastly Lake Natron area $(12.55 \% \pm 5.54 \%)$. For Oryx density (Figure 12 ), similar trend was maintained with Amboseli area leading with $0.02 \pm 0.00$ Oryx (per $\mathrm{km}^{2}$ ), with the rest of the locations having similar densities lead by Magadi/Namanga area $(0.01 \pm 0.01$ Oryx per $\mathrm{km}^{2}$, West Kilimanjaro area $\left[0.01 \pm 0.01\right.$ Oryx per $\left.\mathrm{km}^{2}\right]$, and lastly Lake Natron area $\left(0.00 \pm 0.00\right.$ Oryx per $\left.\mathrm{km}^{2}\right)$.

Considering changes (percent) in the density in each of the locations of the borderland between 2010 and 2013, West Kilimanjaro area had the highest positive average 


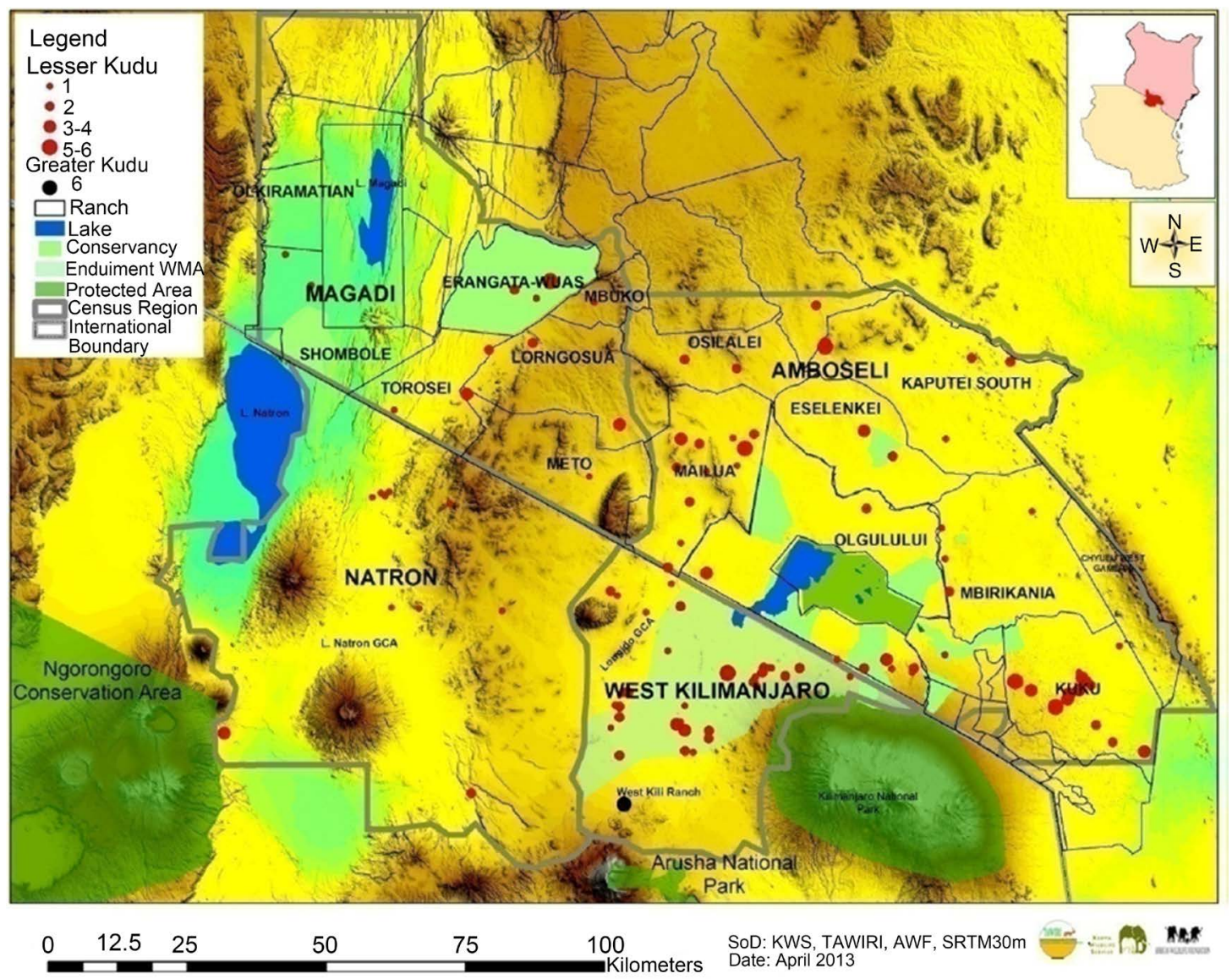

Figure 10. Lesser kudu distribution in the Kenya-Tanzania borderland during the 2013 wet season census.

Table 9. Oryx numbers and density in the key population hotspots of the Kenya/Tanzania borderland.

\begin{tabular}{|c|c|c|c|c|c|c|}
\hline Location & Year & Season & $\begin{array}{c}\text { Census area } \\
{\left[\mathrm{km}^{2}\right]}\end{array}$ & $\begin{array}{c}\text { Oryx } \\
\text { numbers }\end{array}$ & $\begin{array}{c}\text { Oryx } \\
\text { density } \\
{\left[\text { per } \mathrm{km}^{2}\right]}\end{array}$ & $\begin{array}{l}\text { Proportion [\%] } \\
\text { Oryx numbers in } \\
\text { the borderland }\end{array}$ \\
\hline \multirow{5}{*}{$\begin{array}{c}\text { Amboseli and } \\
\text { surrounding group } \\
\text { ranches }\end{array}$} & \multirow{2}{*}{2010} & Wet & 8797.00 & 168 & 0.02 & 85.71 \\
\hline & & Dry & 8797.00 & 49 & 0.01 & 62.82 \\
\hline & \multirow{2}{*}{2013} & Wet & 9214.44 & 187 & 0.02 & 35.08 \\
\hline & & Dry & 9214.44 & 139 & 0.02 & 57.44 \\
\hline & \multicolumn{2}{|c|}{$\begin{array}{c}\text { Overall } \\
{[\text { Mean } \pm \text { SE }]}\end{array}$} & - & $135.8 \pm 30.6$ & $0.02 \pm 0.00$ & $60.16 \pm 10.30$ \\
\hline \multirow{5}{*}{$\begin{array}{c}\text { Magadi/Namanga } \\
\text { Areas }\end{array}$} & \multirow{2}{*}{2010} & Wet & 5513.00 & 24 & 0.00 & 12.24 \\
\hline & & Dry & 5513.00 & 1 & 0.00 & 1.28 \\
\hline & \multirow{2}{*}{2013} & Wet & 6348.32 & 191 & 0.03 & 35.83 \\
\hline & & Dry & 63.48 .32 & 13 & 0.00 & 5.37 \\
\hline & \multicolumn{2}{|c|}{$\begin{array}{c}\text { Overall } \\
{[\text { Mean } \pm \text { SE }]}\end{array}$} & - & $57.3 \pm 44.8$ & $0.01 \pm 0.01$ & $13.79 \pm 7.72$ \\
\hline \multirow{4}{*}{$\begin{array}{c}\text { West Kilimanjaro } \\
\text { Area }\end{array}$} & \multirow{2}{*}{2010} & Wet & 3014.00 & 4 & 0.00 & 2.04 \\
\hline & & Dry & 3014.00 & 8 & 0.00 & 10.26 \\
\hline & \multirow{2}{*}{2013} & Wet & 3013.18 & 66 & 0.02 & 12.38 \\
\hline & & Dry & 3013.18 & 71 & 0.02 & 29.34 \\
\hline
\end{tabular}




\section{Continued}

\begin{tabular}{|c|c|c|c|c|c|c|}
\hline & $\begin{array}{r}\mathrm{O} \\
{[\mathrm{Mea}}\end{array}$ & $\begin{array}{l}\text { all } \\
\mathrm{SE}]\end{array}$ & - & $37.3 \pm 18.1$ & $0.01 \pm 0.01$ & $13.50 \pm 5.73$ \\
\hline \multirow{5}{*}{ Lake Natron Area } & \multirow{2}{*}{2010} & Wet & 7047.00 & 0 & 0.00 & 0.00 \\
\hline & & Dry & 7047.00 & 20 & 0.00 & 25.64 \\
\hline & \multirow{2}{*}{2013} & Wet & 7047.26 & 89 & 0.01 & 16.70 \\
\hline & & Dry & 7047.26 & 19 & 0.00 & 7.85 \\
\hline & \multicolumn{2}{|c|}{$\begin{array}{c}\text { Overall } \\
{[\text { Mean } \pm \text { SE }]}\end{array}$} & - & $32.0 \pm 19.5$ & $0.00 \pm 0.00$ & $12.55 \pm 5.54$ \\
\hline
\end{tabular}

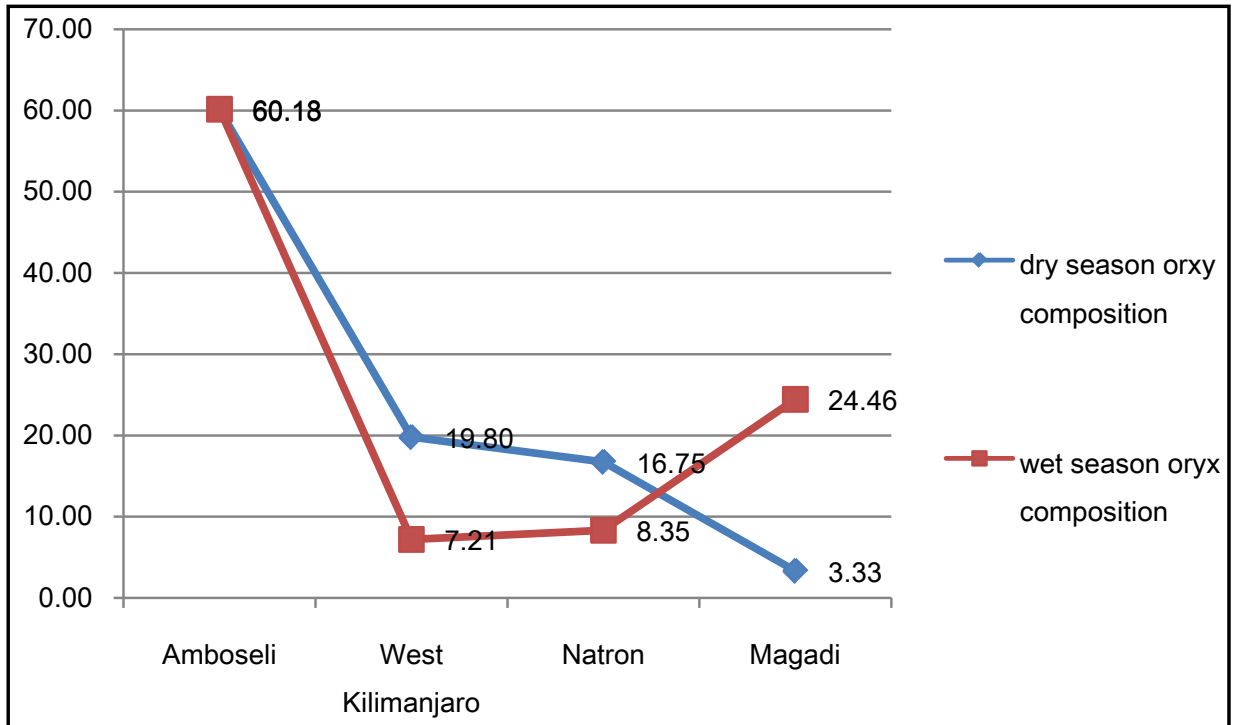

Figure 11. Oryx composition [\%] in the wet and dry season in the Kenya/Tanzania borderland.

Table 10. Oryx numbers and density changes in wet and dry seasons between 2010 and 2013.

\begin{tabular}{|c|c|c|c|c|c|}
\hline Location & Season & $\begin{array}{c}\text { Oryx } \\
\text { density } \\
{\left[\text { per } \mathrm{km}^{2}\right]} \\
{[\text { mean } \pm \mathrm{SE}]}\end{array}$ & $\begin{array}{c}\text { Oryx \% } \\
\text { numbers in } \\
\text { location } \\
{[\text { mean } \pm \mathrm{SE}]}\end{array}$ & $\begin{array}{c}\text { Change }[\%] \text { in } \\
\text { Oryx density over } \\
3 \text { years }\end{array}$ & $\begin{array}{l}\text { Change }[\%] \text { in } \\
\text { Oryx proportion } \\
\text { over the } 3 \text { years }\end{array}$ \\
\hline \multirow{3}{*}{$\begin{array}{l}\text { Amboseli and } \\
\text { surrounding } \\
\text { group ranches }\end{array}$} & Wet & $0.02 \pm 0.00$ & $60.18 \pm 25.10$ & +6.27 & +11.31 \\
\hline & Dry & $0.01 \pm 0.00$ & $60.13 \pm 2.69$ & +170.82 & +183.67 \\
\hline & Overall & $0.02 \pm 0.00$ & $60.16 \pm 10.30$ & $+88.54 \pm 82.28$ & $+97.49 \pm 86.18$ \\
\hline \multirow{3}{*}{$\begin{array}{c}\text { Magadi and } \\
\text { Namanga } \\
\text { Areas }\end{array}$} & Wet & $0.02 \pm 0.01$ & $24.26 \pm 11.57$ & +591.12 & +695.83 \\
\hline & Dry & $0.00 \pm 0.00$ & $3.33 \pm 2.04$ & +1028.94 & +1200.00 \\
\hline & Overall & $0.01 \pm 0.01$ & $13.79 \pm 7.72$ & $+810.03 \pm 218.91$ & $+947.92 \pm 252.08$ \\
\hline \multirow{3}{*}{$\begin{array}{c}\text { West } \\
\text { Kilimanjaro } \\
\text { Area }\end{array}$} & Wet & $0.01 \pm 0.01$ & $7.21 \pm 5.18$ & +1550.45 & +1550.00 \\
\hline & Dry & $0.01 \pm 0.01$ & $19.80 \pm 9.54$ & +787.74 & +787.50 \\
\hline & Overall & $0.01 \pm 0.01$ & $13.50 \pm 5.73$ & $+1169.10 \pm 381.35$ & $+1168.75 \pm 381.25$ \\
\hline \multirow{3}{*}{$\begin{array}{c}\text { Lake Natron } \\
\text { Area }\end{array}$} & Wet & $0.01 \pm 0.01$ & $8.35 \pm 8.35$ & $\begin{array}{l}\text { No animals in } \\
2010 \text { wet season }\end{array}$ & $\begin{array}{l}\text { No animals in } \\
2010 \text { wet season }\end{array}$ \\
\hline & Dry & $0.00 \pm 0.00$ & $16.75 \pm 8.89$ & -5.00 & -5.00 \\
\hline & Overall & $0.00 \pm 0.00$ & $12.55 \pm 5.54$ & - & - \\
\hline
\end{tabular}




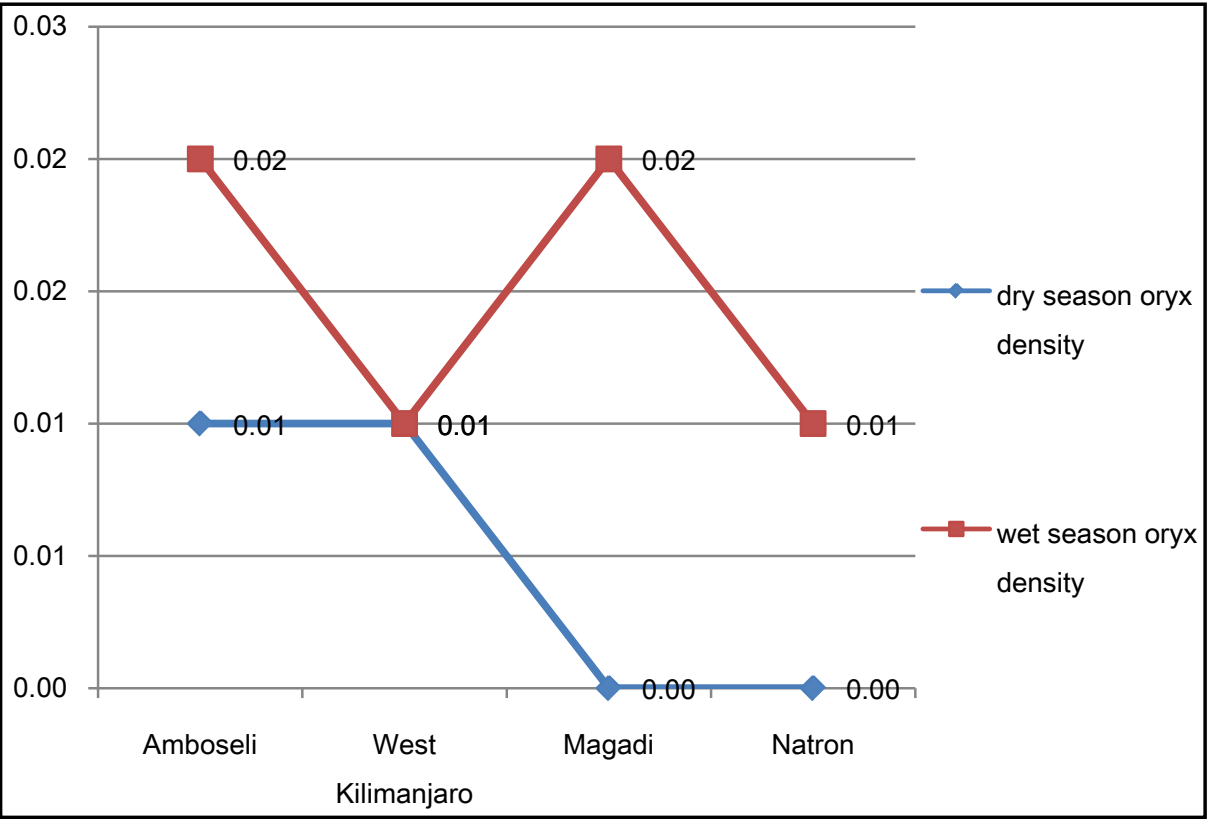

Figure 12. Ryx densities [per $\mathrm{km}^{2}$ ] in the wet and dry season in the Kenya-Tanzania borderland.

percent change (increase) in Oryx density $(+1169.10 \pm 381.35)$, compared to other locations in the borderland (Table 10). The second positive growth in Oryx density was seen in Magadi/Namanga area $(+810.03 \pm 218.91)$. This was followed by Amboseli area $(+88.54 \pm 82.28)$, and lastly Lake Natron area which had a slight decline in Oryx in the dry season $(-5.00 \%)$, but the wet season percent changes in density could not be determined as there were no Oryx counted in Lake Natron area in wet season 2010 (Table 10).

In terms of changes (percent) in the Oryx number composition of the locations in the borderland between 2010 and 2013, similar trend as in changes with density was observed [Table 10]. West Kilimanjaro area had the highest positive average percent change (increase) in Oryx numbers $(+1168.75 \pm 381.25)$, compared to other locations in the borderland (Table 10). The second positive growth in Oryx numbers was also seen in Magadi/Namanga area $(+947.92 \pm 252.08)$. This was followed by Amboseli and surrounding group ranches area $(+97.49 \pm 86.18)$. Lastly, Lake Natron area had witnessed a decline of $-5.00 \%$ in dry season Oryx numbers but the wet season change in numbers could not be determined as there were no Oryx seen in this area in the census of 2010 wet season (Table 10).

There were higher wet season changes in Oryx density and composition in West Kilimanjaro area only. However, higher dry season changes occurred in Amboseli, Magadi and Lake Natron areas. The higher dry season change differences in both density and composition occurred in West Kilimanjaro area, followed by Magadi, Amboseli and lastly Lake Natron area. Oryx decline in density and numbers occurred only in Lake Natron area (Table 10).

Wet and dry season numbers of Oryx over time varied from with location in the 
borderland (Table 11). For Amboseli area and the surrounding area in 2010, wet season number was higher $(\mathrm{p}<0.001)$ than dry season number. Similarly in 2013 , wet season number was higher $(\mathrm{p}=0.008)$ than the dry season number. For the set of wet season number, Oryx number was similar $(\mathrm{p}=0.31)$, with a negligible increase in 2013, But for the dry season, Oryx number in 2013 was higher $(\mathrm{p}<0.001)$ than for 2013 (i.e. Oryx number was increasing with time particularly in the dry season) in Amboseli area (Table 11). For Magadi/Namanga area in 2010, wet season number was higher ( $\mathrm{p}$ 0.001 ) than the dry season number. Similarly for 2013, the wet season number was higher $[\mathrm{p}<0.001]$ than the dry season number. For both sets of wet season, and dry season, Oryx $t$ number in 2013 was higher ( $p<0.001$ in all cases) than for 2010 (i.e. Oryx number increased with time for both seasons) in Magadi/Namanga area (Table 11).

For West Kilimanjaro in 2010, wet season and dry season numbers were similar ( $\mathrm{p}=$ 0.25 ), with dry season being non-significantly higher than wet season. Similarly for 2013 , wet season and dry season numbers were similar $(p=0.67)$, with dry season

Table 11. Oryx number comparisons between seasons and within season in various locations within the Kenya-Tanzania borderland.

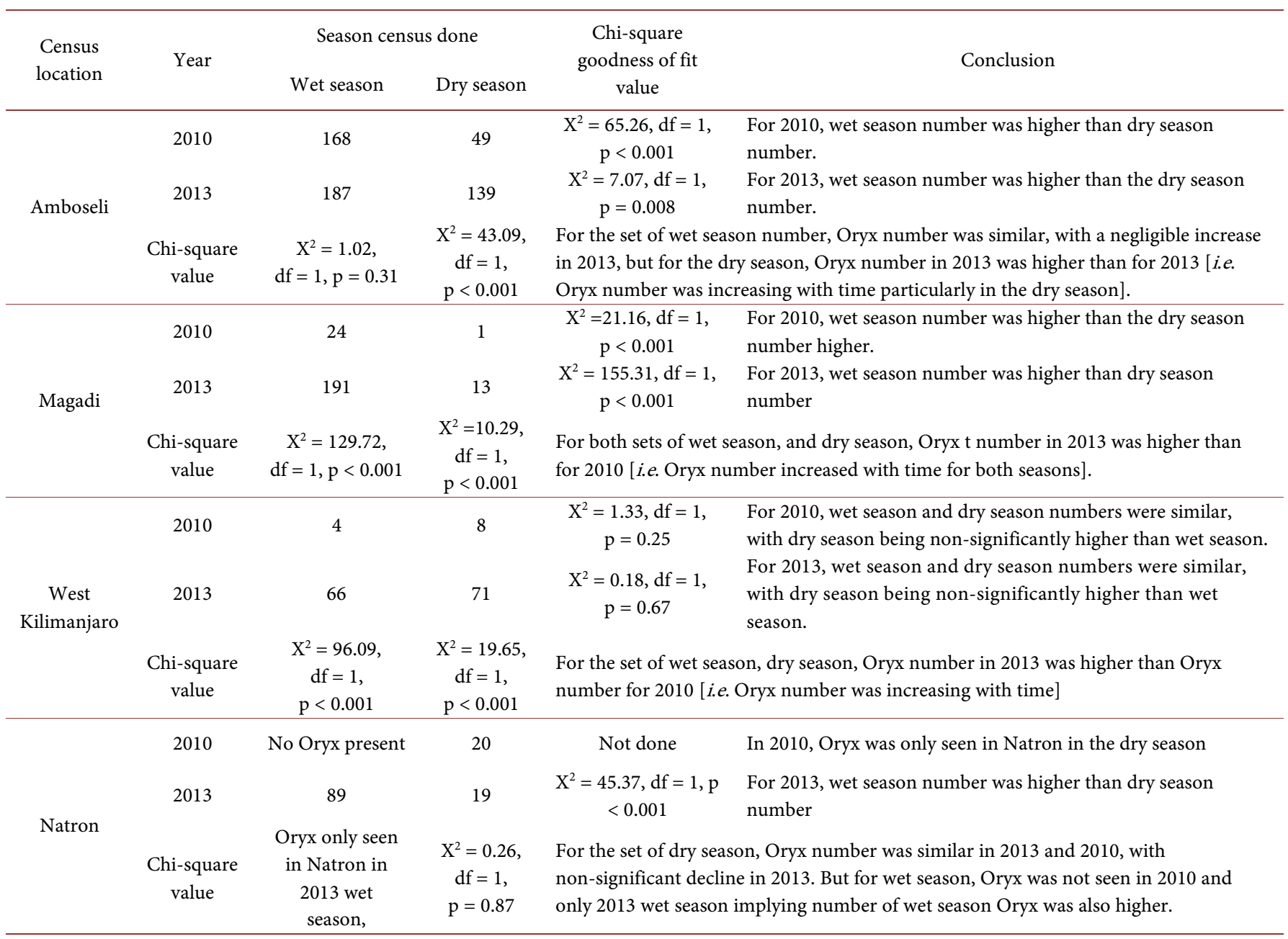


being non-significantly higher than wet season. However, for the set of wet season, and dry season, Oryx number in 2013 was higher ( $p<0.001$ in all cases) than Oryx number for 2010 (i.e. Oryx number was increasing with time) in West Kilimanjaro area (Table 11). For Lake Natron area in 2010, Oryx were only seen in the dry season and not wet season. However for 2013, wet season Oryx number was higher $(\mathrm{p}<0.001)$ than dry season number. Further, for the set of dry season, Oryx number was similar $(\mathrm{p}=0.87)$ in 2013 and 2010, with non-significant decline in 2013. But for wet season, Oryx was not seen in 2010 and only 2013 wet season implying number of wet season Oryx was also increasing in Lake Natron area (Table 11).

In terms relationships between Oryx numbers in different locations (closer or further away from protected areas), influence of seasons on Oryx numbers varied among the locations in the borderland (Table 12). Generally, Oryx numbers in locations was dependent (cross tabulations, $\mathrm{p}<0.001$ ) on the season, with numbers both closer and further away from protected areas being higher in the wet season than try season. Specifically, in the wet season, Oryx number in locations was dependent $(\mathrm{p}<0.001)$ of year, with numbers in both closer and further from protected areas increasing with time. Further, in the dry season, Oryx number in locations was dependent $(\mathrm{p}=0.005)$ on year, with numbers in both closer and further from protected areas increasing with time (Table 12).

Oryx were distributed in specific areas in clumped numbers in only two places in

Table 12. The relationship between Oryx numbers and census location proximity to existing protected areas [Amboseli and West Kilimanjaro] and away [Magadi and Lake Natron area] within the borderland.

\begin{tabular}{|c|c|c|c|c|c|}
\hline \multirow[b]{2}{*}{$\begin{array}{c}\text { Season } \\
\text { of the } \\
\text { year }\end{array}$} & \multicolumn{3}{|c|}{ Location of census area } & \multirow[b]{2}{*}{$\begin{array}{l}\text { Chi-square } \\
\text { cross } \\
\text { tabulation } \\
\text { value }\end{array}$} & \multirow[b]{2}{*}{ Conclusion } \\
\hline & Year & $\begin{array}{c}\text { In or } \\
\text { around } \\
\text { protected } \\
\text { areas }\end{array}$ & $\begin{array}{c}\text { Away } \\
\text { from } \\
\text { protected } \\
\text { areas }\end{array}$ & & \\
\hline $\begin{array}{c}\text { Wet } \\
\text { season }\end{array}$ & $\begin{array}{c}2010 \\
\text { [after drought] } \\
2013 \\
\text { [post drought] }\end{array}$ & 172 & 280 & $\begin{array}{c}\mathrm{X}^{2}=95.68 \\
\mathrm{df}=1 \\
\mathrm{p}<0.001\end{array}$ & $\begin{array}{l}\text { In the wet season, Oryx } \\
\text { number in locations was } \\
\text { dependent of year, with } \\
\text { numbers in both closer and } \\
\text { further from protected areas } \\
\text { increasing with time. }\end{array}$ \\
\hline $\begin{array}{c}\text { Dry } \\
\text { season }\end{array}$ & $\begin{array}{c}2010 \\
\text { [after drought] } \\
2013 \\
\text { [post drought] }\end{array}$ & 210 & 32 & $\begin{array}{c}\mathrm{X}^{2}=8.01 \\
\mathrm{df}=1 \\
\mathrm{p}=0.005\end{array}$ & $\begin{array}{l}\text { In the dry season, Oryx } \\
\text { number in locations was } \\
\text { dependent on year, with } \\
\text { numbers in both closer and } \\
\text { further from protected areas } \\
\text { increasing with time. }\end{array}$ \\
\hline $\begin{array}{l}\text { Wet } \\
\text { season }\end{array}$ & & 425 & 304 & & $\begin{array}{l}\text { Generally, Oryx numbers in } \\
\text { locations was dependent on }\end{array}$ \\
\hline $\begin{array}{c}\text { Dry } \\
\text { season }\end{array}$ & & 267 & 53 & $\begin{array}{c}\mathrm{X}^{2}=62.60 \\
\mathrm{df}=1 \\
\mathrm{p}<0.001\end{array}$ & $\begin{array}{l}\text { the season, with numbers } \\
\text { both closer and further away } \\
\text { from protected areas being } \\
\text { higher in the wet season than } \\
\text { try season. }\end{array}$ \\
\hline
\end{tabular}


Amboseli area and one place in West Kilimanjaro in the dry season. But in the wet season, the Oryx spread much more but in clusters in Mbirikani area of Amboseli and a few places in West Kilimanjaro, Natron and Magadi (Figure 13).

\section{Discussion and Conclusions}

The three species were all very poorly represented both in distribution and numbers. This is worrying because each of these species is in itself very important in the savanna ecology and very unique member of the herbivore guild in the borderland [17]. The clumped distribution in small areas in the borderland indicates a serious general decline in these species and isolation. Even though all of them are still present in Amboseli area, their number is small. In other areas, the species is actually facing local extinction. For example, gerenuk, lesser kudu, and Oryx are rarely now seen in the Magadi and some areas of Namanga and the few that remain are in group ranches of Amboseli and a small area in West Kilimanjaro.

For the three species, Only Amboseli and surrounding group ranches seemed to have sizeable number of the four species, but West Kilimanjaro, Lake Natron and Namanga seemed to have very few numbers of the species. Further, the densities were much lower. In terms of sheer numbers, lesser kudu was relatively the rarest followed by gerenuk

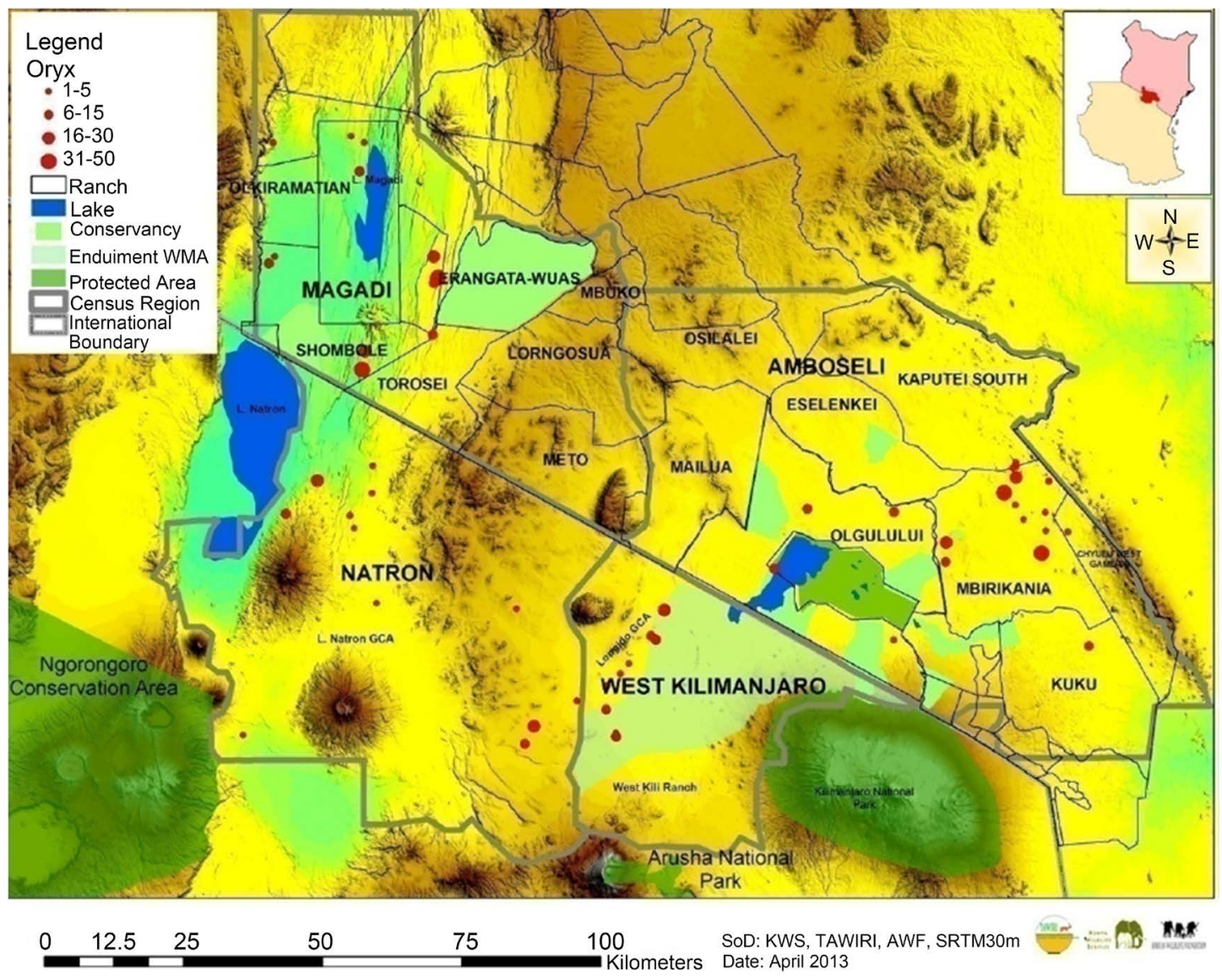

Figure 13. Oryx distribution in the Kenya-Tanzania borderland during the 2013 wet season census. 
and Oryx across the locations, but the number of all these four species was in similar range, about 100 in Amboseli but less than 50 for all other species in other locations [17] [18]. With also lower densities, it is likely that these species are maintaining very low population sizes and densities for healthier mating encounters and interactions. They are therefore more prone to local extinctions because of stochastic events such as droughts, long dry season, scarcity of forage due to competition with other herbivores and few mating encounters [Allee effect]. It is therefore likely that droughts will have a more severe effect to the small population and local extinctions are especially in other areas of the borderland outside Amboseli Ecosystem.

Lesser kudu and gerenuk were the rarest among the four species. These two species change in density and numbers indicated that even though they were more abundant in Amboseli ecosystem, the rapid growth in density and numbers was occurring in West Kilimanjaro and Magadi/Namanga area implying that these areas had potential to be re-colonized after the 20007 and 2009 droughts and despite low population numbers and density, lesser kudu and gerenuk numbers can increase. This is possible if improving habitat conditions following the return of normal rains is supported by antipoaching operations in the borderland, especially in West Kilimanjaro and Magadi/ Namanga area. Therefore gerenuk and lesser kudu have a great potential for populations increase and build-up again in West Kilimanjaro and Magadi/Namanga areas after the droughts. The fact that there was no negative [decline] change in the gerenuk and lesser kudu numbers and density attested to the potential for these populations to increase again in the other borderland locations other than Amboseli Ecosystem. Amboseli ecosystem, despite having the bulk of these four species, also had relatively a good positive [increase] change in lesser kudu than in gerenuk implying the significance of Amboseli as the location with most of the animal numbers of these two species, but also potential for further population increase, if poaching and habitat destruction are contained.

The Oryx is the commonest of the three rare species, with numbers, particularly in Amboseli Ecosystem being relatively higher. However, the changes in numbers and density were quite different for these two species. The Oryx change in density and numbers indicated that rapid growth in density and numbers was occurring in West Kilimanjaro and Magadi/Namanga area implying that these areas had potential to be re-colonized after the 20007 and 2009 droughts and potential for the increase in the population numbers and density of Fringe-eared Oryx. Lake Natron area had a decline in Oryx density and composition in the dry season and lack of Oryx in the wet season of 2010 implies that there may be a possibility of local extinction of this species in Lake Natron area (although re-colonization as seen in wet season 2013 is possible) from a combination of habitat destruction, poaching and drought effects.

Gerenuk and lesser kudu belong to different tribes of antelopes, with gerenuk belonging to antilopini with gazelles while the lesser kudu tragelaphini with other spiralhorned antelopes such as eland and bushbuck [2]. But gerenuk and lesser kudu low density and numbers in the borderland may also be explained from its highly selective 
foraging and habitat type preferences. Gerenuk is found in a variety of habitats with hoody vegetation, but is common in dry, flat, open thon bushes where it can move around easily when foraging. Lesser kudu on the hand prefers dense bushland [and not open ones preferred by gerenuk] that they use for thermal and predation cover. However, the two species are the purest of browsers, feeding on small tree leaves, flowers and pods and rarely grazing. Gerenuk is the most specialized of the two species as a concentrate feeder, and so habitat destruction and modification by human activities and overgrazing, especially during droughts, will greatly affect its feeding success and therefore survival. Lesser kudu however, can also feed on some young grass and succulent plants such as sisal in the dry season, drinking where necessary, therefore making it more able to survive drought and habitat impacts than gerenuk. However, this special habitat preferences and similar forage needs makes them more vulnerable to changes in habitats, human impacts and effects of droughts on their survival and population viability.

Oryx belongs to the antelope tribe of Hippotragini with other horse-like antelopes such as roan and sable. Oryx is one of the perfect desert-adopted large mammals, capable of subsisting in dry wastelands where other ungulates [hoofed mammals] cannot survive. It prefers green grass, but also eats dry grass. It also can browse to some extent, digging out roots, tubers and eating wild fruits such as wild melon and cucumbers which provide not only food but also water [2]. It also conserves water through metabolic adaptations as well as choosing to forage at night or very early in the morning to take advantage of water in dew. This makes it more adoptable to drought than other ungulates and able to ranges further in such of water.

These species also form part of the prey of the common carnivore species such as lion and hyena in the in the Kenya/Tanzania borderland [18]. Their population sizes are therefore important their decline will be likely be associated with less natural food for the carnivores in the savannah ecosystem. Therefore, lack of sufficient and diverse herbivore prey species for the carnivores, especially when they are decimated by droughts, will lead to these carnivores turning to livestock (mainly goats, sheep and cattle) and hence lead to elevated cases of human-carnivore conflicts compared to situations where these species were common as prey for top carnivores in the ecosystem.

Generally for all herbivores, dry season and droughts see reduced water, green forage and thermal cover, all which are critical for herbivore survival and population growth [17]. Dry season and droughts, despite causing more direct mortality on these species than any other time of the year, they may lead to age-sex dependent mortality where most young and old, and possibly females than males are killed. This selective mortality can destabilize evolutionary age-sex adaptive state and cause depressed breeding success with disruption of social organization of these species, and particularly death of many territorial males who may opt to remain in their territory even when forage if completely depleted. Recovery from the high general mortality and effects of social disruption in the population of these species may mean longer time needed for popula- 
tion recovery from prolonged droughts and dry season. This recovery can be further delayed where there is environmental degradation leading to poor habitats and increased human-wildlife conflicts due to competition for common resources [water, pasture and space] with livestock and humans. More studies on direct and indirect effect of droughts on these species should be done to provide more insights in constraints to population recovery even after droughts are over and the habitat and environmental conditions have improved.

But generally, the finding these species were increasing with time after the 2007 and 2009 droughts mean that they were on the way to full recovery in the borderland. But even though this can be seen as a positive aspect of building back these species population, it is likely that these buildup will remained localized to suitable habitats and where these species are safe from impacts of people and will only begin to disperse in the borderland landscape with less impacts from human encroachment, poaching by bush meat and habitat destruction. Management attention should be focused on Lake Natron and Magadi/Namanga areas of the borderland because they had lowest numbers and recovery rate of these species. With increasing of numbers in every wet season, and for every passing year in areas closer and away from protected areas, there is great potential and opportunity to get the numbers of these four species to build up again and become viable populations of the borderland Meta-population, whose other populations are now faced with local extinction in several locations.

Lastly, the safety of these and other large mammal species in the borderland is critical for allowing for re-colonization of the space where wildlife large mammals in the borderland can again live after the droughts [17]. Reduced conflicts with wild herbivores over damages (may be due to crop raiding and in some cases competition for water, pasture and space), and threats (such as bush meat poaching) and habitat destruction will lead to a steady large herbivore decline in the borderland [19] [20] [21]. We need to establish what other human-induced mortality has led to a decline of these four species and take remedial action. In this regard, continued cross border collaborative management and population monitoring (between Kenya and Tanzania) is very essential. Further, joint effort in ground population monitoring and undertaking anti-poaching that allow positive population growth and dispersal of large wild mammals as the follow water availability and new forage production [22] in the borderland landscape will enhance the new legal obligations of countries in cross border conservation collaboration in East Africa.

\section{References}

[1] East, R. (1999) African Antelope Database 1998. IUCN/SSC Antelope Specialist Group. IUCN Species Survival Commission Occasional Paper No 21. IUCN, Gland, Switzerland and Cambridge, UK.

[2] Estes, R.D. (2012) The Behaviour Guide to African Mammals, including Hoofed Mammals, Carnivores and Primates. The University of California Press.

[3] Leuthold, W. (1978) Ecology of the Gerenuk Litocranius walleri. Journal of Animal Ecology, 47, 561-580. http://dx.doi.org/10.2307/3801 
[4] International Union for Conservation of Nature [IUCN] SSC Antelope Specialist Group (2008) IUCN Red List of Threatened Species. Version 2010.2.

[5] Kahurananga, J. (1981) Population Estimates, Densities and Biomass of Large Herbivores in Simanjiro Plains, Northern Tanzania. African Journal of Ecology, 19, 225-238. http://dx.doi.org/10.1111/j.1365-2028.1981.tb01061.x

[6] Stanley-Price, M.R.S. (1978) Fringe-Eared Oryx on a Kenya Ranch. Oryx, 14, 370-373. http://dx.doi.org/10.1017/S0030605300015982

[7] King, J.M. (1979) Game Domestication for Animal Production in Kenya: Field Studies of the Body-Water Turnover of Game and Livestock. Journal of Agricultural Science, 93, 7179. http://dx.doi.org/10.1017/S0021859600086147

[8] NOOA (2008) DROUGHTS: Public Fact Sheet. National Weather Service. http://www.nws.noaa.gov/os/brochures/climate/DroughtPublic2.pdf

[9] PDNA (2011) Kenya Post-Disaster Needs Assessment [PDNA] 2008-2011 Drought. Government of Kenya, Nairobi.

[10] Pratt, D.J. and Gwynne, M.D. (1977) Rangeland Management and Ecology in East Africa. Hodder and Stoughton, London, England.

[11] Okello, M.M. and D'Amour, D.E. (2008) Agricultural Expansion within Kimana Electric Fences and Implications for Natural Resource Conservation around Amboseli National Park, Kenya. Journal of Arid Environments, 72, 2179-2192. http://dx.doi.org/10.1016/j.jaridenv.2008.07.008

[12] Ntiati, P. (2002) Group Ranches Subdivision Study in Loitokitok Division of Kajiado District. Land Use Change Impacts and Dynamics (LUCID) Working Paper 7, International Livestock Research Institute (ILRI), Nairobi.

[13] Reid, R., Gachimbi, L., Worden, J., Wangui, E., Mathai, S., Campbell, D., Maitima, J., Butt, B., Gichohi, H. and Ogol, E. (2004) Linkages between Changes in Land Use, Biodiversity and Land Degradation in the Loitokitok Area of Kenya. Land Use Change Impacts and Dynamics [LUCID] Working Paper Series 49, 1-29.

[14] Douglas-Hamilton, I., Gachago, S., Litoroh, M. and Mirangi, J. (1994) Tsavo Elephant Count 1994. Report to the Kenya Wildlife Service, Nairobi.

[15] Zar, J.H. (1999) Biostatistical Analysis. 4th Edition, Prentice Hall, Upper Saddle River.

[16] Dirschl, H., Norton-Griffiths, M. and Wetmore, S.P. (1981) Training Observers for Aerial Surveys of Herbivores. Wildlife Society Bulletin, 9, 108.

[17] Croze, H. and Lindsay, W.K. (2011) Amboseli Ecosystem Context: Past and Present. In: Moss, C.J., Croze, H. and Lee, P.C., Eds., The Amboseli Elephants, a Long-Term Perspective on a Long-Lived Mammal, The University of Chicago Press, Chicago and London, 1128. http://dx.doi.org/10.7208/chicago/9780226542263.003.0002

[18] Grimshaw, J.M., Cordeiro, N.J. and Foley, C.A.H. (1995) The Mammals of Kilimanjaro. Journal of the East Africa Natural History Society, 84, 105-139. http://dx.doi.org/10.2982/0012-8317(1995)84[105:TMOK]2.0.CO;2

[19] Berger, D. (1993) Wildlife Extension: Participatory Conservation by the Maasai of Kenya. ACTS Environmental Policy Series No. 4, 5-45.

[20] Okello, M.M. (2005) Land Use Changes and Human-Wildlife Conflict in the Amboseli Area, Kenya. Human Dimensions of Wildlife, 10, 19-28. http://dx.doi.org/10.1080/10871200590904851

[21] Western, D., Groom, R. and Worden, J. (2009) The Impact of Subdivision and Sedentarization of Pastoral Lands on Wildlife in an African Savanna Ecosystem. Biological Conserva- 
tion, 142, 2538-2546. http://dx.doi.org/10.1016/j.biocon.2009.05.025

[22] Western, D. (1975) Water Availability and Its Influence on the Structure and Dynamics of a Savannah Large Mammal Community. East African Wildlife Journal, 13, 265-285.

http://dx.doi.org/10.1111/j.1365-2028.1975.tb00139.x

Submit or recommend next manuscript to SCIRP and we will provide best service for you:

Accepting pre-submission inquiries through Email, Facebook, LinkedIn, Twitter, etc. A wide selection of journals (inclusive of 9 subjects, more than 200 journals)

Providing 24-hour high-quality service

User-friendly online submission system

Fair and swift peer-review system

Efficient typesetting and proofreading procedure

Display of the result of downloads and visits, as well as the number of cited articles Maximum dissemination of your research work

Submit your manuscript at: http://papersubmission.scirp.org/

Or contact nr@scirp.org 